\title{
Taxonomic changes in Persoonia (Proteaceae) in New South Wales
}

\author{
Peter H. Weston and L.A.S. Johnson
}

\begin{abstract}
Weston, Peter H. \& Johnson, L.A.S. (National Herbarium of New South Wales, Royal Botanic Gardens, Sydney, NSW, Australia 2000) 1991. Taxonomic changes in Persoonia (Proteaceae) in New South Wales. Telopea 4(1): 269-306. The Persoonia nutans - P. myrtilloides species group is circumscribed and revised, and a key to the group and descriptions of all taxa are provided. Miscellaneous other new taxa are described, and several names are reinstated from synonymy. We discuss the taxonomic status of a number of formal and informal taxa listed in 'Plants of New South Wales' by Jacobs and Pickard. Thirteen new species are described: Ptrsoonia acuminata L. Johnson \& P. Weston, P. asperula L. Johnson \& P. Weston, P. bargoensis P. Weston \& L. Johnson, P. conjuncta P. Weston \& L. Johnson, P. cuspidifera L. Johnson \& P. Weston, P. isophylla L. Johnson \& P. Weston, P. laxa L. Johnson \& P. Weston, P. katerae P. Weston \& L. Johnson, P. oleoides L. Johnson \& P. Weston, $P$. procumbens L. Johnson \& P. Weston, $P$. rufa L. Johnson \& P. Weston, $P$. terminalis L. Johnson \& P. Weston, and P. volcanica P. Weston \& L. Johnson. Four new subspecies are described: $P$. hirsuta Pers. subsp. evoluta L. Johnson \& P. Weston, P. laurina Pers. subsp. intermedia L. Johnson \& P. Weston, P. laurina Pers. subsp. leiogyna L. Johnson \& P. Weston and $P$. terminalis subsp. recurva $\mathrm{L}$. Johnson \& P. Weston. Two new combinations are made: P. brevifolia (Benth.) L. Johnson \& P. Weston, P. myrtilloides Sieber ex Schultes \& Schultes f. subsp. cunninghamii (R. Br.) L. Johnson \& P. Weston. Lectotypes are designated for several species.
\end{abstract}

\section{Introduction}

In the course of our revisionary work on Persoonia in eastern Australia we have recognised the existence of a number of new taxa. We have also concluded that it is appropriate to reclassify some named taxa at new ranks. In this paper we have formally made most of these additions and changes so that they are available for the forthcoming second volume of the 'Flora of New South Wales'. Since all of the taxa in the informal $P$. nutans - P. myrtilloides group are subjects of taxonomic change, we are presenting a revision of that group. New taxa and combinations in Persoonia mollis are treated by Krauss and Johnson (this issue). In addition, we have concluded that a number of the 'taxa' of Persoonia referred to by informal names in Jacobs and Pickard (1981) should not be recognised. We have discussed these here to justify their exclusion from our Flora account.

We have attributed authorship of many of our new taxa to 'L. Johnson \& P. Weston'. This is deliberate; they should not be cited as 'L. Johnson \& P. Weston ex P. Weston \& L. Johnson'. The number in brackets following each 'selected specimens' heading refers to the total number of specimens seen.

Codes used to indicate conservation status of rare or endangered taxa follow the conventions outlined by Briggs and Leigh (1988: 7-13); see summary of codes at back of issue. 


\section{Morphology}

Some of the morphological terms that we use require definition or discussion.

We have classified hairs as either short (longest hairs equal to or less than $0.5 \mathrm{~mm}$ long), of moderate length (longest hairs more than $0.5 \mathrm{~mm}$ long but less than or equal to $1.5 \mathrm{~mm}$ long) or long (more than $1.5 \mathrm{~mm}$ long). Where hairs are present, their density is classified as sparse (only a few, scattered hairs), moderately dense (more than a few scattered hairs but not so dense that the underlying epidermis is obscured), or dense (obscuring the underlying epidermis).

Patterns of leaf venation are described as either brochidodromous, following Hickey (1973), or obscure (in preference to Hickey's synonymous term hyphodromous). In brochidodromous venation the basic arrangement of mid- and lateral veins is pinnate but each lateral vein loops distally as it approaches the margin, joining the next most distal lateral vein. Venation is classed as obscure if its pattern is not externally visible in dried leaves.

Inflorescences are described using the terminology of Briggs and Johnson (1979). The inflorescence in all species of Persoonia is a botryum, 'A simple blastotelic inflorescence in which the primary axis bears lateral flowers' (Briggs \& Johnson 1979: 241). Botrya in Persoonia are either auxotelic (the inflorescence axis continues to grow beyond the flowering region into a leafy shoot) or anauxotelic (the inflorescence axis terminates in an aborted vegetative bud at the end of the flowering region of the shoot). Usually the flower-subtending organs (pherophylls) in anauxotelic inflorescences are exclusively scale leaves. In auxotelic inflorescences, however, usually only one or a few basal flowers are subtended by scale leaves, while the more distal flowers are subtended by fully developed leaves. There is often a transition in the pherophylls of an auxotelic inflorescence from basal scale leaves through reduced leaves to full-sized foliage leaves.

Plants of most species of Persoonia that produce anauxotelic inflorescences also produce auxotelic inflorescences. The proportion of auxotelic to anauxotelic inflorescences varies amongst these species so the variation in percentages of inflorescence types on a typical herbarium specimen is included in the descriptions. For example, the inflorescences of $P$. oleoides are described as 'anauxotelic (0-92\%) or auxotelic (100$8 \%)^{\prime}$. This means that in the herbarium material examined, the percentage of anauxotelic inflorescences on each specimen varied from $0 \%$ to $92 \%$. That is, some specimens had only auxotelic inflorescences while in others up to $92 \%$ were anauxotelic.

The tips of the tepals of many species of Persoonia are caudate and in bud the tepaltips of most of these species are coherent, or almost so. In several species such as P. myrtilloides Sieber ex Schultes \& Schultes f., however, structures that appear to be the homologues of caudate tepal-tips of other species occupy a slightly subterminal position on the abaxial tepal surface. The four tepal-tips in a flower bud are free from each other and may even be recurved to reflexed as in P. myrtilloides.

All of the taxa dealt with in this paper share the following characters: anther appendages absent, flowers virtually actinomorphic (the gynoecium is only apparently radially symmetrical, consisting of one carpel with 1-2 laterally attached ovules), gynoecium almost as long as the tepals, anthers held close to one another and to the gynoecium at their bases but each anther recurving (to varying degrees from species to species) towards the tip. 


\section{A revision of the Persoonia nutans - $P$. myrtilloides group}

The Persoonia nutans - P. myrtilloides species group may be defined as consisting of those species of Persoonia sens. lat. that have: flowers \pm actinomorphic, anther appendages absent, either flowers borne on recurved pedicels or leaves less than 1.2 $\mathrm{cm}$ long, and gynoecium consistently glabrous. Whether this group is a clade or just an arbitrarily defined class remains to be determined. However, the species are phenetically similar and one of the characters that all but one of the species share, recurved pedicels, could well prove to be a synapomorphy for the group.

The pedicels in this group are erect to strongly recurved in flower. However, they elongate and usually become more strongly recurved in fruit. There is little doubt that recurved pedicels are apomorphous within Persoonia. All of the other genera in the Persoonioideae, Placospermum, Garnieria, Toronia and Acidonia sens. strict., have erect pedicels, as do the species groups that are cladistically basal within Persoonia (Weston 1983). Although several other species of Persoonia, viz. P. graminea R. Br., P. sericea Cunn. ex R. Br., $P$. fastigiata R. Br. and P. oblongata R. Br. also have recurved pedicels, it can be argued that all of these are more closely related to other taxa and that their recurved pedicels evolved convergently.

The Western Australian P. graminea seems to be most closely related to an unnamed species from the Stirling Range that has erect pedicels. Together these species seem to be most closely related to a larger group that has erect pedicels (Weston 1983).

$P$. sericea and $P$. fastigiata consistently possess hairy ovaries, a feature that may group them as sister species, relative to the other taxa that resemble them most closely, $P$. rigida, $P$. cuspidifera and $P$. curvifolia. It seems unlikely that these species are closely related to the $P$. nutans $-P$. myrtilloides group or any of its constituent species.

$P$. oblongata resembles the $P$. nutans $-P$. myrtilloides group more closely but it differs in having leaves that are always twisted at the base so that the lamina lies in a vertical plane, and is concolorous with flat margins. Also, individual specimens of this species often possess a hairy ovary. These characters suggest that $P$. oblongata may be more closely related to $P$. marginata, a species with erect pedicels.

The only species in the $P$. nutans - P. myrtilloides group in which the pedicels are not recurved, even in fruit, is $P$. terminalis. This species has relatively small leaves, a character that it shares with $P$. acuminata, $P$. recedens, $P$. oxycoccoides, $P$. microphylla and $P$. asperula. If small leaves is a synapomorphy grouping these species, then erect pedicels probably evolved secondarily in $P$. terminalis. $P$. terminalis has relatively very short (1-2 mm) pedicels and perhaps this feature precludes the development of recurvature.

One of us (LJ in Jacobs \& Pickard 1981) had earlier treated P. nutans sens. lat. as a widespread, geographically variable species that included seven informal subspecies. We now believe that those subspecies (plus two additional taxa that were referable to P. nutans sens. lat.) are best treated as species (one with two subspecies). Our reasoning for this changed circumscription is set out below.

Most of the taxa previously included in $P$. nutans sens. lat. ( $P$. nutans, $P$. bargoensis, $P$. laxa, $P$. acuminata, $P$. recedens, $P$. terminalis, $P$. oxycoccoides, $P$. microphylla and $P$. asperula) are morphologically quite distinct. Earlier we had thought that $P$. bargoensis consisted of specimens sampled from a cline linking $P$. nutans and $P$. oxycoccoides. After further sampling, however, it became clear that $P$. bargoensis is a discrete taxon. Only $P$. oxycoccoides and $P$. acuminata seem to intergrade and they do so in a geographically limited area. 
It might then be suggested that $P$. acuminata should be reduced to a subspecies of $P$. oxycoccoides. However, there is no apparent synapomorphy linking these taxa, so a more broadly circumscribed $P$. oxycoccoides could well be paraphyletic. Although some taxa such as $P$. myrtilloides and $P$. terminalis possess clear synapomorphies, overall the $P$. nutans - P. myrtilloides group cannot at present be resolved in terms of precise cladistic relationships.

Another approach would be to expand the limits of $P$. nutans further to include $P$. myrtilloides and P. brevifolia as well. However, $P$. myrtilloides and $P$. recedens occur sympatrically in the higher Blue Mountains with only sporadic hybridisation and it is clear that these taxa are reproductively isolated from each other, thus warranting specific rank.

It should be noted that $P$. nutans subsp. C in Jacobs and Pickard (1981) comprises two species recognised here, $P$. acuminata and $P$. recedens. Specimens collected since subsp. $C$ was circumscribed (by LJ in the early 1950s) have emphasised the distinctiveness of the populations in the higher Blue Mountains so that it now seems reasonable to recognise them formally. The name $P$. oxycoccoides Sieber ex Sprengel was misapplied in being listed as a synonym of $P$. nutans subsp. C in Jacobs \& Pickard (1981). The type of $P$. oxycoccoides is a specimen of the taxon that was then treated as $P$. nutans subsp. E.

The species that were previously included in $P$. nutans sens. lat. as subspecies show a geographic replacement pattern, with the different species occurring in different habitats and often separated by major topographic barriers such as river valleys.

The following is a general description of the $P$. nutans - P. myrtilloides species group.

Prostrate to erect shrubs. Bark smooth. Hairs whitish to greyish, appressed to patent. Leaves not consistently twisted, not pungent, green when fresh. Flowers \pm actinomorphic. Pedicels erect to recurved. Tepals yellow. Anthers yellow, lacking appendages. Ovary glabrous.

The species are ordered on the basis of apparent phenetic similarity.

\section{Key to species}

1 Width:length ratio of leaves $1: 7$ to $1: 20$, leaves usually linear, mostly $<2.0 \mathrm{~mm}$ wide

2 Leaves linear-lanceolate to lanceolate

$2^{*}$ Leaves linear-oblong

3 Erect to spreading shrub; leaves $1.5-3.0 \mathrm{~cm}$ long, strongly discolorous when dried

10. P. nutans

$3^{*}$ Prostrate or decumbent shrub; leaves $0.8-1.5 \mathrm{~cm}$ long, slightly discolorous when dried

11. P. laxa

$1^{*}$ Width:length ratio of leaves $>1: 7$, leaves not linear, $1.2-30 \mathrm{~mm}$ wide

4 Tepals prominently caudate with recurved to reflexed tips 1.P. myrtilloides

$4^{*} \quad$ Tepals apiculate to acute or shortly caudate with straight tips

5 Leaves mostly $<2.0 \mathrm{~mm}$ wide, $0.4-1.1 \mathrm{~cm}$ long; inflorescences mostly terminal, anauxotelic

8. P. terminalis

$5^{*}$ Leaves usually $>2.0 \mathrm{~mm}$ wide, $0.3-2.5 \mathrm{~cm}$ long; inflorescences terminal or axillary, auxotelic

6 Mature leaves scabrous with antrorse to patent hairs; leaves convex with recurved to revolute margins, broad-elliptical to ovate to broadovate

7. P. microphylla

$6^{*}$ Mature leaves smooth and glabrescent to scaberulous with appressed hairs; leaves flat with flat to recurved margins, ovate 
7 Pedicels sparsely to moderately hairy; tepals glabrous to moderately hairy; leaves sparsely to moderately hairy when immature, remaining so when mature

6. P. asperula

$7^{*}$ Pedicels and tepals glabrous (or rarely the pedicels very sparsely hairy); leaves sparsely (or rarely moderately) hairy when immature, glabrescent to sparsely hairy when mature

8 Longest leaves $1.1 \mathrm{~cm}$ long or less ..... 5. P. oxycoccoides $8^{*} \quad$ Longest leaves $>1.1 \mathrm{~cm}$ long

9 Leaves acute, concolorous to slightly discolorous, with flat to slightly recurved margins, $1.2-3.5 \mathrm{~mm}$ wide $\quad .$.

4. $P$. recedens

9* Leaves usually acuminate, usually strongly discolorous, with recurved margins, $2.5-8.5 \mathrm{~mm}$ wide

10 Tepals shortly caudate; leaves and flowers usually turning dark brown to black on drying

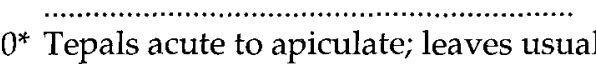

2. P. brevifolia brown on drying

3. P. acuminata

\section{Persoonia myrtilloides Sieber ex Schultes $\mathcal{E}$ Schultes $f$.}

(Schultes \& Schultes 1827: 272)

Type Citation: 'Sieber. Herb. nov. Holl. Nro. 52.'

LECTOTYPE (here designated): M. ResiduAL SYNTYPES: K, M, MEL, NSW, NY.

Linkia myrtilloides (Sieber ex Schultes \& Schultes f.) Kuntze (Kuntze 1891: 579).

Erect to spreading shrubs, $0.5-2.5 \mathrm{~m}$ high. Hairs of moderate length $(0.1-0.8 \mathrm{~mm}$ long), appressed to patent. Young branchlets moderately hairy; internodes $0-15(-38) \mathrm{mm}$ long. Leaves alternate, narrowly to broadly elliptic to ovate, acuminate to mucronate, 1.2 $5.0 \mathrm{~cm}$ long, 4-30 mm wide, flat, with slightly recurved margins, spreading to suberect, sometimes slightly incurved, not falcate, sparsely to moderately hairy when immature, glabrescent when mature, smooth to moderately scabrous; midvein usually evident on both surfaces, venation brochidodromous but often obscure. Inflorescences auxotelic, 1-40-flowered; rachis $0-17 \mathrm{~cm}$ long; flowers subtended by scale leaves or leaves. Pedicels $2-10 \mathrm{~mm}$ long, spreading to recurved, sparsely to moderately hairy. Tepals 9-12 mm long, prominently caudate with recurved to reflexed tips, sparsely to moderately hairy. Ovules 2. Drupes green suffused with purple. Cotyledons 4-6.

FLOWERING PERIOD: December to April.

Distribution: From the upper Goulburn River through the Wollemi district to Wentworth Falls in the upper Blue Mountains, in eastern New South Wales.

Notes: $P$. myrtilloides seems to be a clade, characterised by synapomorphous tepaltips. These are caudate, like the tepal-tips of many other species of Persoonia, but they are subterminal on what appears to be the abaxial tepal surface, and recurved to prominently reflexed. It most closely resembles $P$. brevifolia, but its cladistic relationships are unclear. The leaves and flowers of both P. brevifolia and P. myrtilloides tend to turn dark brown to black on slow drying, while other species in the P. nutans - P. myrtilloides group turn paler brown. This feature might be a synapomorphy for these species but it is one that occurs in other members of the Proteaceae, including several other species of Persoonia.

P. myrtilloides often occurs sympatrically, and occasionally hybridises, with $P$. recedens, $P$. acerosa and $P$. levis. It also sometimes grows with $P$. chamaepitys, $P$. linearis and P. laurina. 
Morphological variation in $P$. myrtilloides is geographically correlated, ranging from populations with small, broad-elliptical leaves and with long, reflexed tepal-tips in the north to those with larger, narrow-elliptical leaves and with shorter, slightly recurved tepal-tips in the south. Geographic variation in leaf morphology seems to be clinal but that in morphology of tepal-tips seems to involve an abrupt transition in the Capertee area. We have chosen (somewhat arbitrarily) to subdivide this geographic variation into two subspecies, on the basis of tepal morphology.

\section{Key to subspecies}

1 Tepal-tips recurved, 1.0-2.0 mm long; leaves narrow-elliptic to lanceolate, 2.0-5.0 cm long, 4-12 mm wide

1a. subsp. myrtilloides

1* Tepal-tips prominently reflexed, $2.5-4.5 \mathrm{~mm}$ long; leaves mostly broad-elliptic to ovate to lanceolate, $1.2-3.8 \mathrm{~cm}$ long, $6-30 \mathrm{~mm}$ wide 1b. subsp. cunninghamii

\section{1a. P. myrtilloides subsp. myrtilloides}

[P. myrtilloides subsp. A in Jacobs \& Pickard (1981: 181)]

HaBrTAT: Dry sclerophyll eucalypt forest or occasionally in woodland or heath, on sandy, stony or clayey soils derived from sandstone, at altitudes from 900 to $1200 \mathrm{~m}$.

Distribution: Higher Blue Mountains from the Capertee Valley south to Wentworth Falls (Figure 1).

CONSERVATION STATUS: not rare.

Selected SPeCimens (49): New South Wales: Central Tablelands: Excelsior, Boorman, Jan 1914 (NSW 21186); Wolgan Gap, Johnson, 17 May 1970 (NSW 23518); $0.7 \mathrm{~km}$ from Bell-Lithgow road on Clarence sawmill road, Weston 377, 21 Jan 1982 (SYD, NSW); Mount Boyce, 33 37'S 150 $10^{\circ} \mathrm{E}$, Coveny 4754 \& Armstrong, 4 Dec 1972 (NSW); Wentworth Falls, Hamilton, Nov 1913 (NSW 21205).

1b. P. myrtilloides subsp. cunninghamii (R. Br.) L. Johnson $\mathcal{E} P$. Weston, comb. et stat. nov.

BASIONYM: Persoonia cunninghamii R. Br. (Brown 1830: 15)

TyPe CitATION: 'Ora orient., prope Port Jackson, 1823. D. Cunningham'. [The ' $D$ ' in this and other $R$. Brown citations is not an initial but stands for 'Dominus', the equivalent of ' $\mathrm{Mr}$ '].

LECTOTYPE (here designated): BM. IsOLECTOTYPEs: K, MEL, NY.

Linkia cunninghamii (R. Br.) Kuntze (Kuntze 1891: 579).

[P. myrtilloides subsp. B in Jacobs \& Pickard (1981: 181)]

НавітAт: Dry sclerophyll eucalypt or Callitris woodland to forest on sandy to stony soils derived from sandstone, at altitudes from 470 to $1000 \mathrm{~m}$.

Distribution: From the upper Goulburn River through the Wollemi district to the Capertee River (Figure 1).

Conservation status: not rare.

Selected specimens (24): New South Wales: Central Tablelands: 2 miles [ $3 \mathrm{~km}$ ] N of Mt Coricudgy, Johnson, 31 Aug 1951 (NSW 21185); Great Dividing Range, 22 km SE of Rylstone, Streimann 835, 15 Dec 1973 (NSW ex CBG). Central Western Slopes: 'The Drips', Goulburn

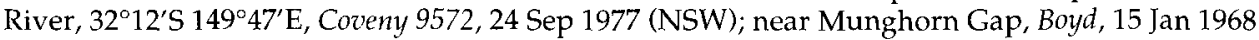
(NSW 71504); $17.1 \mathrm{~km}$ NE of Rylstone on road to Growee Gulph, 32 $40^{\circ} \mathrm{S} 150^{\circ} 01^{\prime} \mathrm{E}$, Coveny 10502 $\mathcal{E}$ Hind, 16 Dec 1979 (NSW). 
2. Persoonia brevifolia (Benth.) L. Johnson \& P. Weston, comb. et stat. nov.

BASTONYM: Persoonia myrtilloides var. brevifolia Benth. (Bentham 1870: 401).

TYPE CITATION: 'Upper Genoa River and Nangatta [Nungatta] mountains up to $4000 \mathrm{ft}$. elevation, F. Mueller'.

SYNTYPES: Upper Genoa River, F. Mueller, Sep 1860 (K, MEL, NSW); Nangatta [Nungatta] mountains, F. Mueller, - (MEL, NSW).

[P. sp. C (aff. myrtilloides) in Jacobs \& Pickard (1981: 182)]

Erect shrub $0.8-1.5 \mathrm{~m}$ high. Hairs of short to moderate length $(0.2-0.6 \mathrm{~mm}$ long),

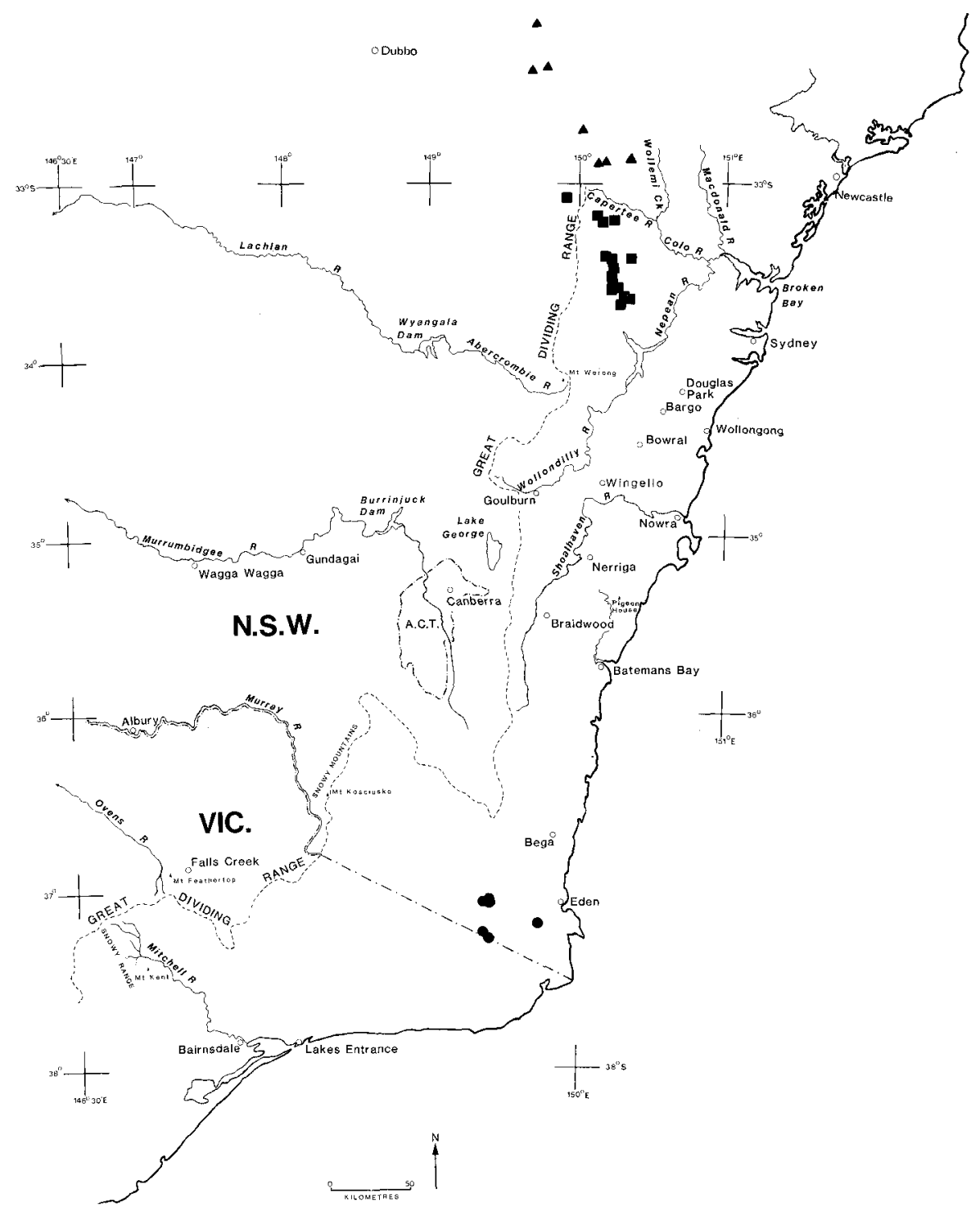

Figure 1. Distributions of Persoonia myrtilloides subsp. myrtilloides (E), p. myrtilloides subsp. cunninghamii $(\boldsymbol{\Lambda})$ and P. brevifolia $(\bullet)$. 
appressed to antrorse. Young branchlets moderately hairy; internodes $0-18(-37) \mathrm{mm}$ long. Leaves alternate, elliptic to broad-elliptic to ovate or obovate, acuminate to mucronate, $1.0-2.5 \mathrm{~cm}$ long, 3-12 $\mathrm{mm}$ wide, flat, with slightly recurved margins, mostly spreading, not falcate, slightly to strongly discolorous, sparsely hairy when immature, glabrescent when mature, smooth; midvein evident on the abaxial surface but otherwise venation obscure. Inflorescences axillary to terminal, auxotelic, 1-10flowered; rachis $0-5.0 \mathrm{~cm}$ long; flowers mostly subtended by leaves. Pedicels $2-5 \mathrm{~mm}$ long, erect to recurved, glabrous to sparsely hairy. Tepals 8-12 $\mathrm{mm}$ long, shortly caudate, glabrous to sparsely hairy. Ovules 1 or 2 . Cotyledons not known.

FLOWERING PERIOD: December to March.

Habitat: Dry to wet sclerophyll eucalypt forest on stony, well-drained soils derived from granitic rocks or sandstone, at 200-1100 m altitude.

Distribution: White Rock Mountain, Mt Wog Wog, Nungatta Peak, and Mt Imlay in far south-eastern New South Wales, also the upper Genoa River in far eastern Victoria (Figure 1).

CONSERVATION STATUS: 2RCa.

Notes: $P$. brevifolia is not known to occur sympatrically with any other species of Persoonia.

Selected spectmens (14): New South Wales: Southern Tablelands: White Rock Mtn, $37^{\circ} 05^{\prime}$ S $149^{\circ} 23^{\prime} \mathrm{E}$, Beesley 315 \& Binns, 26 Mar 1985 (NSW ex CBG); Wog Wog Mtn, 3706' S $149^{\circ} 25^{\prime} \mathrm{E}$, J.D. Briggs $1795 \mathcal{E}$ Weston, 26 Mar 1985 (NSW ex CANB); summit of Mt Imlay, 37 $11^{\circ}$ 'S $149^{\circ} 44^{\prime} \mathrm{E}$, Albrecht 196 \& Conn, 21 Feb 1984 (NSW ex MEL). VICTORIA: slopes above S bank of Yambulla Ck, $37^{\circ} 17^{\prime} \mathrm{S} 149^{\circ} 23^{\prime} \mathrm{E}$, Albrecht 3696,8 Sep 1988 (NSW ex MEL).

\section{Persoonia acuminata L. Johnson $\mathcal{E}$ P. Weston, sp. nov.}

Folia plerumque acuminata, $0.8-2.2 \mathrm{~cm}$ longa, $2.5-8.5 \mathrm{~mm}$ lata, plana marginibus recurvis, plerumque valde discoloria, immaturitate sparse pilosa, maturitate laevia glabrescentiaque. Pedicelli tepalaque glabra. Antherae flavae, sine appendice. Ovarium glabrum.

Holotype: New SOuth Wales: Northern Tablelands: Racecourse Track, $0.4 \mathrm{~km}$ NE of junction with Werrikimbe Trail, $31^{\circ} 08^{\prime} \mathrm{S} 152^{\circ} 18^{\prime} \mathrm{E}$, P.H. Weston 1169 \& P.G. Richards, 30 Jan 1988 (NSW).

P. oxycoccoides var.? longifolia Benth. (Bentham 1870: 401)

Type citation: 'New England, C. Stuart'.

TYPE: not found, but a specimen of $P$. acuminata at K labelled 'New England', collected by $C$. Moore, was determined as var. longifolia by Bentham.

[P. nutans subsp. C p.p. in Jacobs \& Pickard (1981: 182)]

Prostrate to spreading shrubs, to $1.7 \mathrm{~m}$ high. Hairs short $(0.1-0.4 \mathrm{~mm}$ long), appressed to antrorse. Young branchlets moderately hairy; internodes $0-10(-30) \mathrm{mm}$ long. Leaves alternate to subopposite, narrowly to broadly elliptical to ovate to obovate or narrowoblong, usually acuminate, $0.8-2.2 \mathrm{~cm}$ long, $2.5-8.5 \mathrm{~mm}$ wide, flat, with recurved margins, usually spreading though sometimes with a prominently recurved tip, not falcate, slightly to strongly discolorous, sparsely hairy when immature, glabrescent to very sparsely so when mature, smooth but sometimes with longitudinal wrinkles abaxially when dried; midvein often evident towards base of abaxial surface but otherwise venation obscure. Inflorescences axillary to terminal, auxotelic, 1-16flowered; rachis $0-7.5 \mathrm{~cm}$ long; flowers mostly subtended by reduced leaves or leaves. 
Pedicels 3-6 mm long, erect to spreading, glabrous. Tepals $7-10 \mathrm{~mm}$ long, apiculate, glabrous, yellow. Ovule 1. Drupes green. Cotyledons not known.

DERIVATION OF EPITHET: Latin acuminatus, acuminate, in reference to the leaf tips.

FLOWERING PERIOD: December to April.

HABITAT: Heath to wet sclerophyll eucalypt forest, at 1000 to $1500 \mathrm{~m}$ altitude, on welldrained soils, usually derived from granite or metasediments, or on basic volcanic substrates in high-rainfall areas.

DistRiBution: Disjunctly distributed from the Ebor district to the Barrington Tops of the Northern Tablelands of New South Wales and the Hampton area on the Central Tablelands (Figures 2, 3).

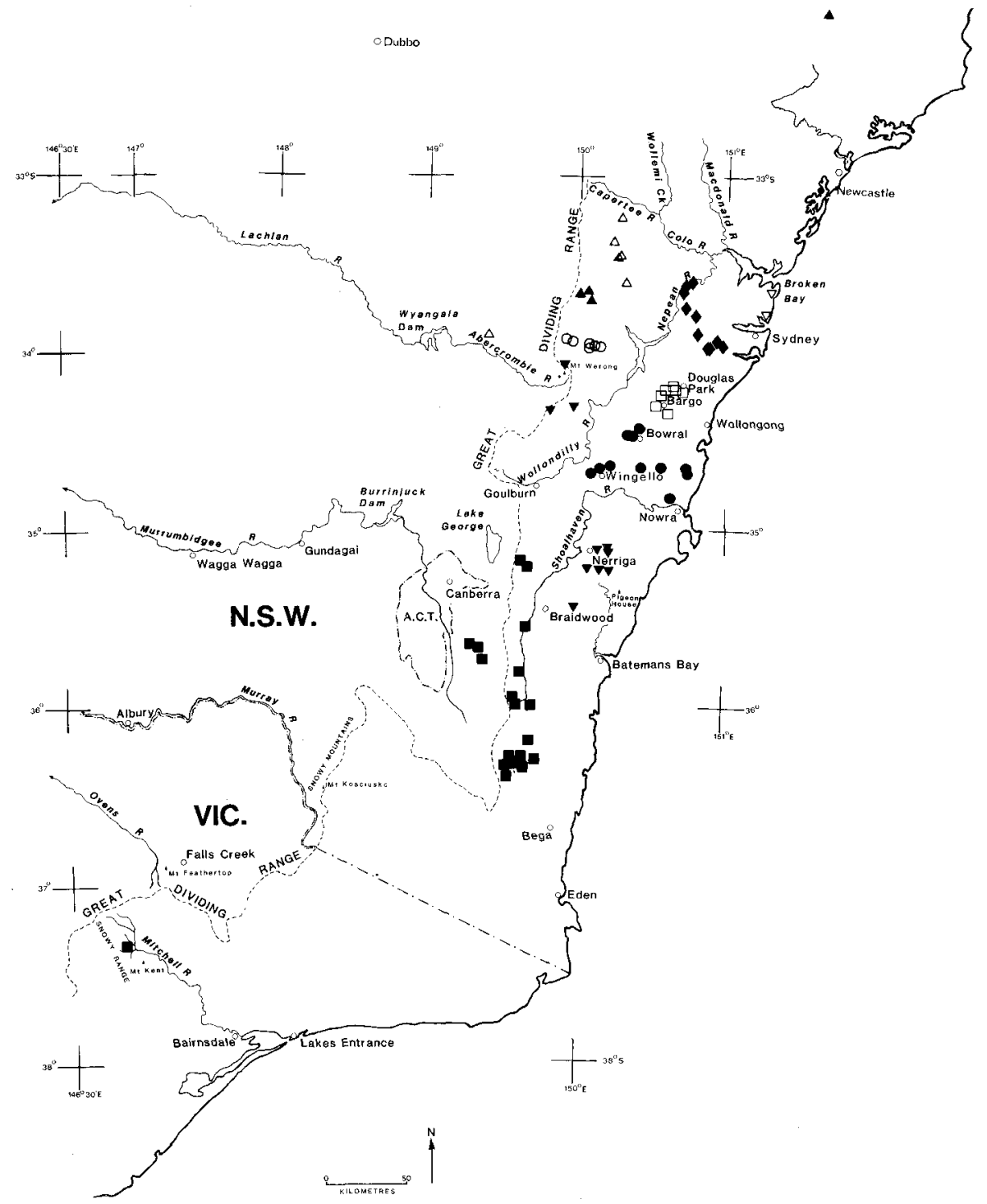

Figure 2. Distributions of Persoonia acuminata (A) (see also Figure 3), P. acuminata $P$. oxycoccoides intergrades $(O), P$ asperula $(\square), P$. bargoensis $(\square), P$. laxa $(\nabla), P$. microphylla $(\nabla), P$. nutans $(\bullet), P$. oxycoccoides $(\bullet)$ and $P$. recedens $(\triangle)$. 


\section{CONSERVATION STATUS: not rare.}

Notes: The other taxon included in $P$. nutans subsp. C in Jacobs and Pickard (1981) was $P$. recedens Gandoger. This taxon is distinguished from P. acuminata by its leaves, which are acute (never acuminate), concolorous to slightly discolorous, with flat to slightly recurved margins, 1.2-3.5 $\mathrm{mm}$ wide.

$P$. acuminata apparently intergrades with $P$. oxycoccoides in a limited area between Jenolan Caves and Kanangra Walls at the southern end of its distribution (see figure 2). These specimens have ovate to broad-ovate or orbicular leaves that, on average, are shorter than those of $P$. acuminata.

The northern populations of $P$. acuminata are separated from $P$. recedens by the Hunter and Capertee River valleys, while to the south these species are separated by the valley of the Coxs River.

Selected specimens (21): New South WAles: Northern Tablelands: Point Lookout, Johnson, 2 Feb 1951 (NSW 17995); Thumb Rd off Hastings Forest Highway, $31^{\circ} 08^{\prime} \mathrm{S} 152^{\circ} 20^{\prime} \mathrm{E}$, Whaite 3758,28 June 1981 (NSW); Dilgry Circle, c. $1 \mathrm{~km} N$ of Dilgry River, $31^{\circ} 53^{\prime} \mathrm{S} 151^{\circ} 32^{\prime} \mathrm{E}$, Rodd 4706 \& Parsons, 21 Aug 1986 (NSW). Central Tablelands: Mt Bindo, $1.3 \mathrm{~km}$ NW of Tower, $33^{\circ} 41^{\prime} \mathrm{S}$ $150^{\circ} 00^{\prime} \mathrm{E}$, Benson 2302 \& Keith, 14 Feb 1985 (NSW).

4. Persoonia recedens Gandoger

(Gandoger 1919: 227)

TYPE CITATION: 'Australia. N.S.Wales. Blackheath. Walter'.

HoLOTYPE: Blackheath N.S.W., C. Walter, Dec 1882 (LYON).

[P. nutans subsp. C p.p. in Jacobs \& Pickard (1981: 182)]

Decumbent to spreading shrubs, 0.3-1.5 m high. Hairs short (0.1-0.4 mm long), appressed. Young branchlets sparsely to moderately hairy; internodes $0-6(-12) \mathrm{mm}$ long. Leaves alternate to subopposite, narrow-oblong to narrow-elliptical, acute, 1.0 $2.0 \mathrm{~cm}$ long, $1.2-3.5 \mathrm{~mm}$ wide, flat, with flat to recurved margins, usually suberect, not falcate, concolorous to slightly discolorous, sparsely hairy when immature, glabrescent when mature, smooth but with prominent longitudinal wrinkles abaxially when dried; venation obscure. Inflorescences axillary to terminal, auxotelic, 1-12flowered; rachis $0-2.3 \mathrm{~cm}$ long; flowers subtended by reduced leaves or leaves. Pedicels 2.0-3.5 mm long, glabrous. Tepals 9-10 mm long, apiculate, glabrous. Ovule 1. Drupes green. Cotyledons not known.

FLOWERING PERIOD: December to January, with sporadic flowering as late as June.

HABITAT: Dry sclerophyll eucalypt forest, at 630 to $1170 \mathrm{~m}$ altitude, on sandy, siliceous soils, usually derived from Narrabeen Sandstone.

Distribution: Newnes Plateau to Blackheath, in central-eastern New South Wales with a dubious, disjunct record from Abercrombie Caves. (Figure 2).

CONSERVATION STATUS: 2R.

Notes: $P$. recedens most closely resembles $P$. acuminata, and occurs between the disjunct parts of the distribution of the latter taxon, on a different substrate (sandstone) and in different plant communities. The supposed Abercrombie Caves locality is open to doubt, since that area differs geologically from the rest of the range of $P$. recedens, and the collector is known to one of us ( $\mathrm{LJ}$ ) to have made occasional (though rare) errors in locality recording.

Selected specimens (13): New South Wales: Central Tablelands: near Bungleboori, Newnes State Forest, $33^{\circ} 24^{\prime} \mathrm{S} 150^{\circ} 12^{\prime} \mathrm{E}$, johnson 8459, 14 Apr 1979 (NSW); $0.7 \mathrm{~km}$ from Bell-Lithgow road on 
Clarence sawmill road, Weston 372, 21 Jan 1982 (SYD, NSW); Blackheath, Betche, Dec 1882 (NSW 20904); Abercrombie Caves, Constable 22 Oct 1958 (NSW 56617).

\section{Persoonia oxycoccoides Sieber ex Sprengel} (Sprengel 1827: 45)

TYPe CitATION: 'Sieb. ... Nov. Holl.'.

Lectotype (here designated): Sieber 49: B. IsOlectotypes: K, M (2 sheets), MEL, NY.

Linkia oxycoccoides (Sieber ex Sprengel) Kuntze (Kuntze 1891: 579).

P. thymifolia Cunn. ex R. Br. (Brown 1830: 15). Type Citation: 'Ora orient., prope Port Jackson, 1823. D. Cunningham.' SYNTYPEs: Argyle, A. Cunningham, Apr 1824 (BM, K).

[P. nutans subsp. E in Jacobs \& Pickard (1981: 182)]

Prostrate to spreading shrubs, to $0.9 \mathrm{~m}$ high. Hairs short $(0.1-0.4 \mathrm{~mm}$ long), appressed to antrorse. Young branchlets sparsely to moderately hairy; internodes $0-6(-10) \mathrm{mm}$ long. Leaves alternate to subopposite, narrowly to broadly elliptical to ovate, acute to acuminate or obtuse, $0.4-1.1 \mathrm{~cm}$ long, $1.5-6 \mathrm{~mm}$ wide, flat, with recurved margins, spreading, not falcate, slightly to strongly discolorous, sparsely to moderately hairy when immature, glabrescent to sparsely so when mature, smooth to slightly scaberulous; venation obscure. Inflorescences axillary to terminal, auxotelic, 1-13-flowered; rachis $0-3.5 \mathrm{~cm}$ long; flowers subtended by reduced leaves or leaves. Pedicels $2-5 \mathrm{~mm}$ long, glabrous or rarely very sparsely hairy. Tepals $8-11 \mathrm{~mm}$ long, acute to apiculate, glabrous. Ovule 1 or rarely the odd flower with 2. Drupes green. Cotyledons 4.

FLOWERING PERIOD: December to April.

НавітAт: Heath to dry sclerophyll eucalypt forest, at 600 to $700 \mathrm{~m}$ altitude, on acid, sandy soils derived from sandstone.

Distribution: An area bounded by Mittagong, Jamberoo Pass and Tallong on the Central Tablelands of New South Wales (Figure 2).

CONSERVATION STATUS: 2RCa.

NoTES: There is more or less clinal variation in leaf shape between the eastern and western parts of the species' range. Longer-, narrower- leaved plants (typical) occur in the west, and shorter-, broader- leaved plants in the east. $P$. oxycoccoides grows sympatrically with $P$. levis, $P$. mollis and $P$. laurina and occasionally hybridises with the first of the species.

Selected specimens (23): New South Wales: Central Tablelands: Mittagong, Dixon, - (NSW 21143); c. $2 \mathrm{~km} \mathrm{~N}$ of Dhruwalga Trig on Jamberoo-Robertson road, Weston 106, 13 Jan 1980 (SYD); near Fitzroy Falls, Gauba, 7 Jan 1953 (NSW ex CBG); Bundanoon, Moore 3593, Dec 1962 (NSW ex CANB); Penrose, Lindsay, Apr 1936 (NSW 21151).

6. Persoonia asperula L. Johnson $\mathcal{E} P$. Weston, sp. nov.

Folia anguste oblonga vel oblonga vel elliptica vel ovata, $0.7-2.2 \mathrm{~cm}$ longa, $2-6 \mathrm{~mm}$ lata, scaberula. Flores regulares. Pedicelli erecti vel patentes, sparse vel modice pilosi. Antherae flavae, sine appendice. Ovarium glabrum.

Holotype: New South WAles: Southern Tablelands: Wadbilliga Fire Trail, c. 25 km SE of Numeralla, 36 $20^{\prime} \mathrm{S} 149^{\circ} 32^{\prime} \mathrm{E}$, L.G. Adams E M.P. Austin 2911, 11 Jan 1973 (NSW). ISOTYPES (n.v.): CANB, CHR, HBG, K, L, MO, US.

[P. nutans subsp. G in Jacobs \& Pickard (1981: 182)] 
Prostrate to erect shrubs, to $2.0 \mathrm{~m}$ high. Bark smooth. Hairs short $(0.1-0.4 \mathrm{~mm}$ long), appressed to antrorse. Young branchlets moderately hairy; internodes $0-8(-20) \mathrm{mm}$ long. Leaves alternate to subopposite, narrow-oblong to oblong to elliptical or less frequently ovate, acute to obtuse, $(0.3-) 0.7-2.2 \mathrm{~cm}$ long, (1-)2-6 mm wide, flat, with recurved margins, spreading, not falcate, concolorous to strongly discolorous, sparsely to moderately hairy when immature, sparsely to moderately so when mature, scaberulous; midvein sometimes evident towards base of abaxial surface but otherwise venation obscure. Inflorescences axillary to terminal, auxotelic, 1-9-flowered; rachis $0-4.5 \mathrm{~cm}$ long; flowers mostly subtended by reduced leaves or leaves. Pedicels 1-5 mm long, erect to spreading, sparsely to moderately hairy. Tepals $9-11 \mathrm{~mm}$ long, acute to apiculate, glabrous to moderately hairy. Ovule 1. Drupes green with purple stripes. Cotyledons 5.

DERIVATION OF EPITHET: Latin asperulus, somewhat rough, referring to the leaves.

FLOWERING PERIOD: January to February, with sporadic inflorescences as late as June.

HaвiтAт: Heath dominated by Allocasuarina nana to wet sclerophyll eucalypt forest, at 900 to $1350 \mathrm{~m}$ altitude, on shallow, stony soils derived from granite or metasediments.

Distribution: From Sandhills Range through the Tinderry and Kybean Ranges to Mt Kydra in New South Wales and in the Moroka River catchment in Victoria (Figure 2).

CONSERVATION STATUS: not rare.

Notes: $P$. asperula most closely resembles $P$. oxycoccoides, which is distinguished by its glabrous or rarely very sparsely hairy pedicels, its glabrous tepals and its leaves, which are sparsely (or rarely moderately) hairy when immature and glabrescent to sparsely hairy when mature.

The single specimen from eastern Victoria, sampled from a population of two plants, differs from the New South Wales specimens in having smaller $(0.3-0.8 \mathrm{~cm}$ long, 1-2 mm wide), narrow-elliptical leaves. It has no flowers, so there may be other differences too. This may belong to a different taxon, but more samples and better material are required before we can confidently classify these plants. The large disjunction between New South Wales and Victorian populations is surprising given the existence of apparently suitable habitats in the intervening area.

$P$. asperula sometimes grows sympatrically with $P$. chamaepeuce and $P$. silvatica and occasionally hybridises with the former species.

Selected SPECimens (23): New South Wales: Southern Tablelands: Sandhills Ra., Hoskinstown to

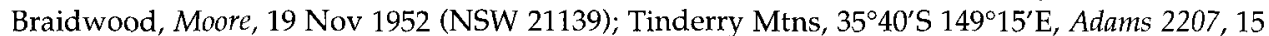
June 1968 (NSW ex CANB); Badja Firetrail, c. 0.3 km from Pikes Saddle, Weston 69 \& Tomlinson, 2 Dec 1979 (SYD); Wadbilliga Fire Trail, $3 \mathrm{~km}$ from Wadbilliga, Tindale $4034 \&$ W Wimbush, 18 Jan 1975 (NSW, BRI, CANB, K, MEL). Victoria: Nielsons Crag, 37²1'S 146º50'E, Walsh 1693, 1 Jan 1987 (NSW ex MEL).

7. P. microphylla $R$. Br.

(Brown 1830: 15)

TYPE CITATION: 'Ora orient., prope Port Jackson, 1823. D. Cunningham.'

HolotrPe: Argyle, A. Cunningham, Apr 1824 (BM).

P. oxycoccoides var. microphylla (R. Br.) Domin (Domin 1921: 584)

[P. nutans subsp. F in Jacobs \& Pickard (1981: 182)]

Prostrate to erect shrubs, to $2.0 \mathrm{~m}$ high. Hairs short $(0.05-0.3 \mathrm{~mm}$ long), mostly antrorse to patent. Young branchlets moderately hairy; internodes $0-3(-6) \mathrm{mm}$ long. Leaves 
alternate to subopposite, broad-elliptical to ovate to broad-ovate, rounded to acute, $0.3-0.9 \mathrm{~cm}$ long, 2-5 mm wide, convex, with recurved to revolute margins, usually recurved towards the tip, spreading at the base, not falcate, slightly discolorous, sparsely to moderately hairy when immature, sparsely so when mature, scabrous; venation obscure. Inflorescences axillary to terminal, auxotelic, 1-14-flowered; rachis 0-3.0 cm long; flowers mostly subtended by leaves. Pedicels $1-3 \mathrm{~mm}$ long, erect to spreading, glabrous to moderately hairy. Tepals $8-10 \mathrm{~mm}$ long, acute to apiculate, glabrous to sparsely hairy. Ovule 1. Drupes green with purple stripes. Cotyledons 4 .

FLOWERING PERIOD: December to February, occasionally with a few sporadic inflorescences throughout the year.

HaBrTat: Heath to dry sclerophyll eucalypt forest, on sandy to stony soils derived from sandstone or other siliceous rocks, at altitudes from 600 to $1200 \mathrm{~m}$.

Distribution: Disjunctly distributed in eastern New South Wales from the Murruin Range towards Taralga on the Great Divide and in the Corang and Endrick River catchments of the Budawang Range (Figure 2).

CONSERVATION STATUS: not rare.

NOTES: P. microphylla grows sympatrically with $P$. mollis subsp. livens in the Nerriga area and occasionally hybridises with it. It also grows sympatrically with $P$. laurina subsp. intermedia and subsp. leiogyna.

Selected SPeCiMens (21): New South Wales: Central Tablelands: Mt Werong - South Head, Murruin Ra., Johnson \& Constable, 24 Oct 1957 (NSW 17756); Richlands to Wombeyan Caves, Moore 2641, 13 Oct 1953 (NSW). Southern Tablelands: Bungonia road, $0.7 \mathrm{~km}$ ESE of junction with

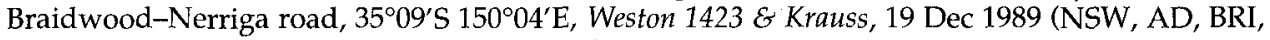
CBG, HO, MEL, PERTH, K, RSA, RB, NBG); head of Endrick River, c. $11 \mathrm{~km}$ SE of Nerriga, Pulley \& Telford BR 330, 20 Dec 1975 (NSW ex CBG); Sallee Creek, $0.5 \mathrm{~km} \mathrm{~S}$ of Fosters Mtn, $35^{\circ} 12^{\prime}$ S $150^{\circ} 10^{\prime}$ E, B.G. Briggs 4744, Sep 1973 (NSW); Charleys Forest, Baeuerlen, Sep 1898 (NSW, CBG, MEL,).

\section{Persoonia terminalis $L$. Johnson \& P. Weston, sp. nov.}

Folia anguste oblonga, $0.35-1.0 \mathrm{~cm}$ longa, $1.2-2.0 \mathrm{~mm}$ lata, convexa marginibus recurvis, non torta. Inflorescentiae plerumque terminales anauxotelicaeque, floribus plerumque in axillis foliorum bractiformium. Flores regulares. Pedicelli $1-2 \mathrm{~mm}$ longi. Antherae flavae, sine appendice. Ovarium glabrum. Ovula 2.

Holotype: New SOUTH WALES: Northern Tablelands: Emmaville-Torrington road, 3.4 $\mathrm{km}$ S of Torrington pub, $29^{\circ} 20^{\prime} \mathrm{S} 151^{\circ} 41^{\prime} \mathrm{E}$, P.H. Weston 1439 \& P.G. Richards, 3 Jan 1990 (NSW). IsOTYPES: AD, BRI, CBG, HO, K, MEL, MO, PERTH, RB.

[P. nutans subsp. D in Jacobs \& Pickard (1981: 182)]

Erect to spreading shrubs, $0.7-1.5 \mathrm{~m}$ high. Bark smooth. Hairs short (0.1-0.5 mm long), appressed to antrorse. Young branchlets sparsely hairy; internodes 0-2(-4) $\mathrm{mm}$ long. Leaves alternate, narrow-oblong, acute, $0.35-1.0 \mathrm{~cm}$ long, $1.2-2.0 \mathrm{~mm}$ wide, convex, with recurved margins, usually slightly to strongly recurved towards the tip, spreading at the base, not falcate, not twisted, not pungent, concolorous to slightly discolorous, green, glabrous to sparsely hairy when immature, glabrescent when mature, smooth to slightly scaberulous; venation obscure. Inflorescences mostly terminal, mostly anauxotelic, 1-5-flowered; rachis $0-0.7 \mathrm{~cm}$ long; flowers mostly subtended by scale leaves. Pedicels 1-2 mm long, erect to spreading, sparsely to moderately hairy. Tepals 9-13 mm long, obtuse to apiculate, sparsely hairy. Ovules 2. Drupes green with purple stripes. Cotyledons 5. 
DERIVATION OF EPITHET: Latin terminalis, terminal, referring to the usually terminal, anauxotelic inflorescences.

FLOWERING PERIOD: December to January, sometimes with a few sporadic inflorescences as late as July.

DistRibution: Disjunctly distributed in the Cecil Plains - Inglewood area in SE. Queensland, and in New South Wales in the Warialda area on the North Western Slopes, and the Torrington-Binghi area on the western side of the far Northern Tablelands.

Notes: One of us (LJ) had earlier treated this taxon as an unnamed subspecies of a polymorphic P. nutans (see Jacobs \& Pickard 1981, as P. nutans subsp. D), that included $P$. oxycoccoides and other taxa as informal subspecies. Stanley \& Ross (1986) treated it, reluctantly, as a subspecies of $P$. oxycoccoides, and we now agree with them that it should be treated as a distinct species. See also our discussion, above, of P. oxycoccoides.

$P$. terminalis is distinguished from its close relatives by its small, coriaceous leaves and the apparently autapomorphous inflorescences that are mostly terminal and anauxotelic, with flowers subtended mostly by scale leaves.

$P$. terminalis grows sympatrically with $P$. cornifolia and $P$. sericea, with which it occasionally hybridises, and $P$. tenuifolia.

We recognise two allopatric subspecies within P. terminalis.

\section{Key to subspecies}

1 Leaves slightly recurved towards the tip; longest leaves $0.8-1.0 \mathrm{~cm}$ long 8a. subsp. terminalis

$1^{*}$ Leaves strongly recurved towards the tip; longest leaves $0.6-0.75 \mathrm{~cm}$ long

8 b. subsp. recurva

\section{8a. P. terminalis subsp. terminalis}

Shrubs $0.9-1.5 \mathrm{~m}$ high. Leaves $0.6-1.0 \mathrm{~cm}$ long, slightly recurved towards the tip. Tepals 10-13 mm long.

Навітат: Dry sclerophyll forest on sandy, stony soils derived from acid granite, at altitudes from 900 to $1100 \mathrm{~m}$.

Distribution: Torrington-Binghi area on the western side of the far Northern Tablelands (Figure 3).

CONSERVATION STATUS: 2R.

Selected SPECIMENS (7): New SOUtH Wales: Northern Tablelands: Bismuth, Boorman, Jan 1916 (NSW 20905); $4 \mathrm{~km}$ from Torrington along road to Emmaville, $29^{\circ} 20^{\prime} \mathrm{S} 151^{\circ} 41^{\prime} \mathrm{E}$, Crisp 7523, 31 Oct 1984 (NSW ex CBG); near Emmaville, Schumacher, July 1954 (NSW 40156).

8b. P. terminalis subsp. recurva $L$. Johnson $\mathcal{E}$ P.Weston, subsp. nov.

Ab subspecie terminali characteribus sequentibus distinguitur: folia $0.35-0.75 \mathrm{~cm}$ longa, apicem versus valde recurva; tepala $9-10 \mathrm{~mm}$ longa.

Holotype: New South Wales: North Western Slopes: Warialda, H.M.R. Rupp, Jan 1907 (NSW 21138).

Shrubs, $0.5-1.0 \mathrm{~m}$ high. Leaves $0.35-0.75 \mathrm{~cm}$ long, strongly recurved towards the tip. Tepals $9-10 \mathrm{~mm}$ long. 
DERIVATION OF EPITHET: Latin recurvus, curved back, referring to the leaf as a whole, not to the margins.

HaвiтAт: Dry sclerophyll forest on sandy soils derived from sandstone, at altitudes from 350 to $450 \mathrm{~m}$.

Distribution: Disjunctly distributed in the Cecil Plains - Inglewood area in SE. Queensland, and in New South Wales in the Warialda area on the North Western Slopes. (Figure 3).

CONSERVATION STATUS: 3R.

Selected specimens (11): New SOUth Wales: North Western Slopes: about 4 miles $[6 \mathrm{~km}]$ SE of Coolatai, Lane 10, Dec 1972 (NSW); Mosquito Ck Rd, $9.1 \mathrm{~km}$ from Warialda, 29³0'S 150 $30^{\circ} \mathrm{E}$, Weston 1104, Johnson \& Hill, 20 Oct 1987 (NSW); Apex Park on Gwydir Highway, $1.6 \mathrm{~km}$ ESE of Warialda, 29³3'S 150³5'E, Coveny 12352 \& Dalby, 10 Sep 1986 (B, BRI, K, NSW, PERTH, RSA). QueEnsland: Darling Downs: SW of Cecil Plains, Hockings \& Cockburn, Sep 1961 (BRI 030185); Whetstone State Forest, Smith 5, Aug 1922 (BRI 261035, 203321, NSW).

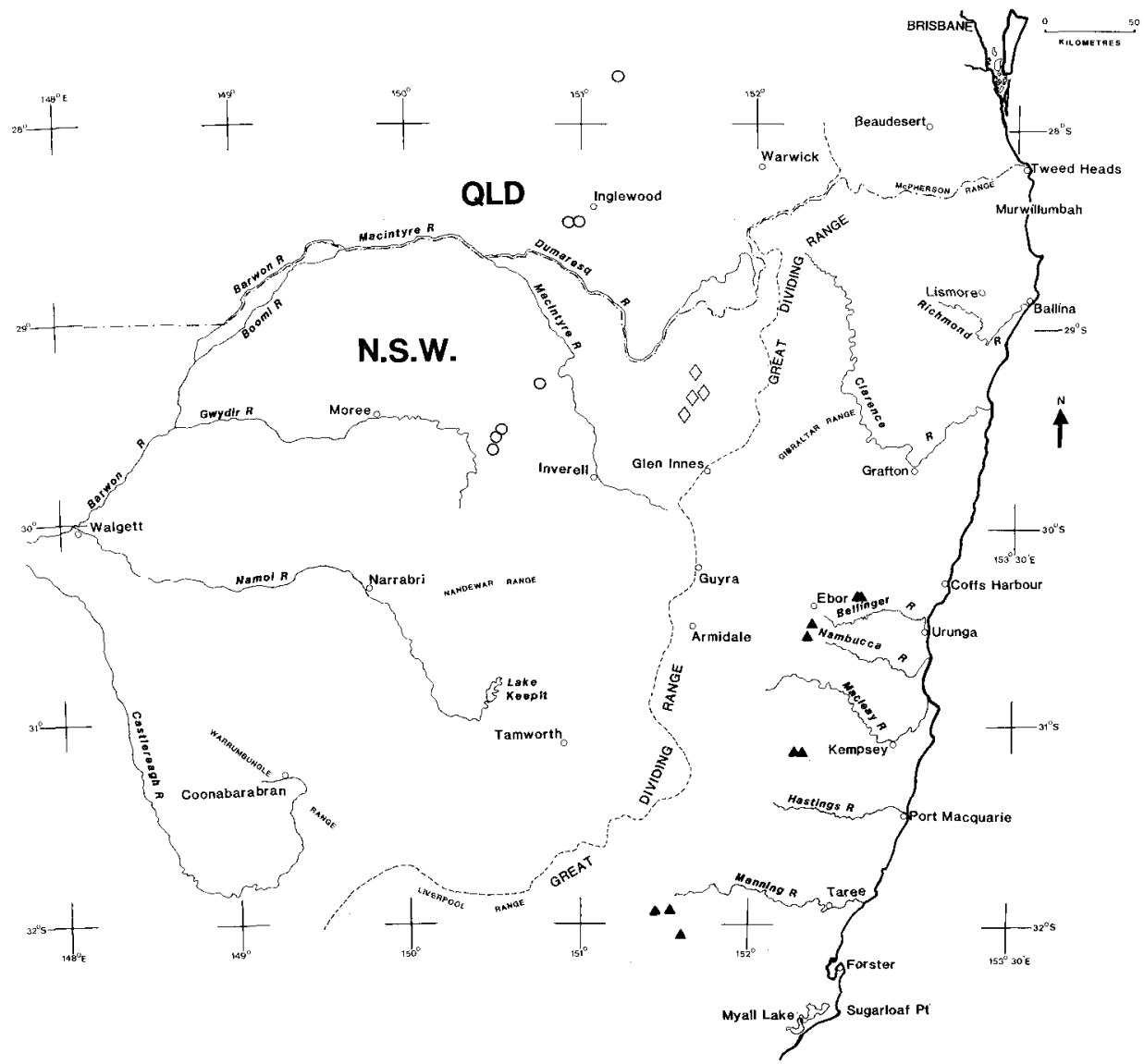

Figure 3. Distributions of Persoonia acuminata (ム) (see also Figure 2), P. terminalis subsp. terminalis $(\diamond)$ and $P$. terminalis subsp. recurva $(O)$. 


\section{Persoonia bargoensis $P$. Weston $\mathcal{E}$ L. Johnson, sp. nov.}

Folia lineari-lanceolata vel lanceolata, $0.8-2.4 \mathrm{~cm}$ longa, $1.0-2.0(-2.3) \mathrm{mm}$ lata, plana vel convexiuscula. Flores regulares. Pedicelli $3-7 \mathrm{~mm}$ longi, patentes vel recurvi, glabri. Tepala glabra. Antherae flavae, sine appendice. Ovarium glabrum.

Holotype: New South Wales: Central Coast: Douglas Park Rd, $0.5 \mathrm{~km}$ SE of bridge over South Western Freeway, $34^{\circ} 12^{\prime} \mathrm{S} 150^{\circ} 42^{\prime} \mathrm{E}$, P.H. Weston 1414 \& S. Krauss, 18 Dec 1989 (NSW). IsOTYPES: AD, BRI, CBG, HO, K, MEL, MO, PERTH, RB.

Erect shrubs, $0.6-2.5 \mathrm{~m}$ high. Hairs short $(0.1-0.4 \mathrm{~mm}$ long), appressed. Young branchlets sparsely to moderately hairy; internodes $0-7(-20) \mathrm{mm}$ long. Leaves alternate, linear-lanceolate to lanceolate, acute to acuminate, $0.8-2.4 \mathrm{~cm}$ long, $1.0-2.0(-2.3) \mathrm{mm}$ wide, flat or convex, with recurved margins, sometimes recurved towards the tip, mostly spreading at the base, not falcate to slightly falcate, slightly to strongly discolorous, green, glabrous to sparsely hairy when immature, glabrescent when mature, smooth; midvein occasionally evident on abaxial surface but otherwise venation obscure. Inflorescences axillary to terminal, auxotelic, 1-20-flowered; rachis 0-6 cm long; flowers mostly subtended by leaves. Pedicels $3-7 \mathrm{~mm}$ long, spreading to recurved, glabrous. Tepals 7-10 mm long, shortly caudate, glabrous, yellow. Anthers yellow. Ovary glabrous. Ovule 1. Drupes green.

DERIVATION OF EPITHET: Refers to its occurrence in the Bargo district of New South Wales.

FLOWERING PERIOD: December to January.

HAвітAт: Dry sclerophyll eucalypt woodland to forest, on Hawkesbury Sandstone and Wianamatta Shale, at altitudes between 100 and $300 \mathrm{~m}$.

Distribution: Catchments of the Cataract, Cordeaux and Bargo Rivers (Figure 2).

CONSERVATION STATUS: $2 \mathrm{~V}$.

Notes: $P$. bargoensis is morphologically intermediate between $P$. nutans and $P$. oxycoccoides and we had earlier thought that the specimens were sampled from a cline between those taxa. It seems clear now, however, that $P$. bargoensis is not part of a cline. Firstly, there is no significant variation evident across its distribution. Secondly, intermediate specimens linking the three taxa have never been collected, despite the accessibility of the relevant areas and attempts to find them. $P$. bargoensis is geographically separated from $P$. nutans by a $40 \mathrm{~km}$ disjunction and from $P$. oxycoccoides by a $25 \mathrm{~km}$ disjunction. It is distinguished from both of those taxa by its linearlanceolate to lanceolate leaves.

No hybrids of $P$. bargoensis are known.

Selected specimens (11): New South Wales: Central Coast: Ripponden [Douglas Park], Caley, Dec 1802 (NSW ex BM); Appin to Wilton road, above Cataract R., 34 $14^{\circ} \mathrm{S} 150^{\circ} 44^{\prime} \mathrm{E}$, Dunn 11 \& James, 1 Nov 1984 (NSW, CBG, MEL); The Pheasants Nest, Nepean River, Constable 6186, 12 Oct 1965 (NSW, BRI); Tahmoor to Bargo, Johnson, 15 Nov 1949 (NSW 18036).

10. Persoonia nutans $R . B r$.

(Brown 1810: 162)

Type Citatron: 'In Novae Hollandiae ora orientali; prope Port Jackson: in sylvis solo arenoso, ad radices montium.'.

Lectotype (here designated): prope Richmond \& fl. Nepean, R. Brown, - (BM). Residual sYNTYPes: Nepean, R. Brown, - (K); Port Jackson, R. Brown, - (NSW ex BM). 


\section{Linkia nutans (R. Br.) Kuntze (Kuntze 1891: 579)}

P. apiculata Meissner (Meissner 1855: 73); P. nutans R. Br. var. apiculata (Meissner) Benth. (Bentham 1870: 402). TyPe Citation: 'Port Jackson.-P. nutans, A. Cunningham! MSS. (non R. Br.)'. HolotyPE: Port Jackson, A. Cunningham, - (NY).

[P. nutans subsp. A in Jacobs \& Pickard (1981: 182)]

Erect to spreading shrub $0.5-1.5 \mathrm{~m}$ high. Hairs short $(0.1-0.4 \mathrm{~mm}$ long), mostly appressed. Young branchlets sparsely to moderately hairy; internodes $0-10(-28) \mathrm{mm}$ long. Leaves alternate, linear-oblong, acuminate, $1.0-4.5 \mathrm{~cm}$ long, $1.0-1.8(-2.5) \mathrm{mm}$ wide, usually flat, with recurved margins, sometimes recurved towards the tip, mostly spreading, sometimes slightly falcate, strongly discolorous, sparsely hairy when immature, glabrescent when mature, smooth; midvein evident on the abaxial surface but otherwise venation obscure. Inflorescences axillary to terminal, auxotelic, 1-40-flowered; rachis 0-25 cm long; flowers subtended by leaves. Pedicels 7-12 mm long, recurved, glabrous. Tepals $8.5-11 \mathrm{~mm}$ long, shortly caudate, glabrous. Ovules 2. Drupes green with purple markings.

FLOWERING PERIOD: November to April with a few flowers as late as July.

Habitat: Dry sclerophyll eucalypt forest, on laterite, Hawkesbury Sandstone or alluvial sand at altitudes below $60 \mathrm{~m}$.

Distribution: Cumberland Plain between Richmond, Macquarie Fields, and East Hills, particularly near the Nepean and Georges Rivers (Figure 2).

CONSERVATION STATUS: $2 \mathrm{E}$.

Notes: $P$. nutans sometimes grows with $P$. laurina and $P$. hirsuta but no hybrids are known. This species is restricted to part of the Sydney metropolitan area and most remaining populations are threatened by development for housing and sand mining.

Selected specimens (32): New South Wales: Central Coast: Hawkesbury Agricultural College, Richmond, Greenwood, 16 Mar 1910 (NSW 21112); Readymix Sand Mine, Londonderry, 3338'S $150^{\circ} 43^{\prime} \mathrm{E}$, Weston $1256 \mathcal{E}$ Catling, 23 Sep 1988 (NSW, K); 1 mile [2 km] E of St Marys, Johnson $\mathcal{E}$ Constable, 22 Dec 1955 (NSW 36554); Kemps Creek, 335'소 15048’E, Coveny 11179, 26 July 1982 (NSW); Georges River opposite East Hills, Whaite 1123, 30 Nov 1951 (NSW); Macquarie Fields, Boorman, Aug 1914 (NSW).

\section{Persoonia laxa $L$. Johnson $\mathcal{E}$ P. Weston, sp. nov.}

Folia linearia, $0.8-1.5 \mathrm{~cm}$ longa, 1-1.8 mm lata, plana marginibus recurvis, laevia. Flores regulares. Pedicelli $6-8 \mathrm{~mm}$ longi, patentes vel recurvi, glabri. Tepala glabra. Appendix antherae absens. Ovarium glabrum.

Holotype: New South Wales: Central Coast: Manly, A.A. Hamilton, June 1908 (NSW 21648).

[P. nutans subsp. B in Jacobs \& Pickard (1981: 182)]

Decumbent or prostrate shrubs. Hairs short (0.1-0.4 mm long), appressed to antrorse. Young branchlets sparsely hairy; internodes $0-5 \mathrm{~mm}$ long. Leaves alternate, linear, 0.8 $1.5 \mathrm{~cm}$ long, 1-1.8 mm wide, flat, with recurved margins, not falcate, slightly discolorous, sparsely hairy when immature, glabrescent when mature, smooth; midvein often evident on the abaxial surface but otherwise venation obscure. Inflorescences axillary to terminal, auxotelic, 1-3-flowered; rachis $0-0.5 \mathrm{~cm}$ long; flowers mostly subtended by leaves. Pedicels 6-8 mm long, spreading to recurved, glabrous. Tepals 8-9 mm long, apiculate, glabrous. Ovary glabrous. Ovules 2. Drupes, cotyledons not known. 
DERIVATTON OF EPITHET: Latin laxus, loose, referring to the habit.

FLOWERING PERIOD: November to January?

HaвiтAт: Presumably in heath or dry sclerophyll eucalypt woodland or forest.

Distribution: Newport to Manly, Central Coast (Figure 2).

CONSERVATION STATUS: $2 X$.

NOTES: This species may be extinct, being represented only by two old specimens collected from what is now a suburban area of Sydney. It most closely resembles $P$. nutans, of which one of us (LJ) had earlier treated it as a subspecies (subsp. B, Jacobs \& Pickard 1981). It differs from P. nutans in its lax, prostrate or decumbent habit, its shorter leaves that are only slightly discolorous, and in its generally shorter pedicels.

A specimen from Dee Why, collected in 1922, held at NSW is morphologically intermediate between $P$. laxa and $P$. levis and could be a hybrid of these species.

Other SPecimen eXamined: New South Wales: Central Coast: Newport, Chapman, 9 Nov 1907 (SYD, NSW).

\section{Miscellaneous new taxa and new combinations}

Weston (1983) was unable to resolve the cladistic relationships of many of the eastern Australian species in detail, so the taxa treated in this section are dealt with in alphabetical order.

\section{Persoonia conjuncta $P$. Weston $\mathcal{E}$ L. Johnson, sp. nov.}

Frutices erecti vel arbusculae 2-7 $\mathrm{m}$ altae. Cortex pro maxima parte laevis sed in trunco subtiliter fissus. Pili breves vel longiusculi, grisei fulvive, antrorsi. Ramuli novelli modice pilosi. Folia anguste elliptica vel lanceolata, 6-14 cm longa, 10-26 mm lata, plana marginibus plusminusve recurvis. Flores regulares. Tepala sparse vel modice pilosa. Antherae flavae, sine appendice. Ovarium pilosiusculum.

HolotYPE: New SOUTH WALES: North Coast: Mt Yarrahapinni, $30^{\circ} 50^{\prime} \mathrm{S} 152^{\circ} 56^{\prime} \mathrm{E}$, L.A.S. Johnson 8516, 23 Jan 1980 (NSW).

ISOTYPES: CBG, $\mathrm{K}$.

Erect shrubs to small trees, 2-7 m high. Bark mostly smooth but finely fissured on trunk. Hairs of short to moderate length $(0.05-0.7 \mathrm{~mm}$ long), greyish to tawny, antrorse. Young branchlets moderately hairy; internodes $0-36 \mathrm{~mm}$ long. Leaves alternate, narrow-elliptical to lanceolate, acute to acuminate to mucronate, 6-14 cm long, 10-26 $\mathrm{mm}$ wide, flat, with recurved margins (often only slightly so), spreading to suberect, not falcate or rarely slightly falcate, twisted through $0-0.25$ turns, not pungent, concolorous to slightly discolorous, green, glabrous to sparsely hairy when immature (but much denser on margins), glabrescent when mature, smooth; venation brochidodromous, evident on both surfaces (though sometimes only faintly so). Inflorescences axillary to terminal, usually auxotelic (60-100\%); auxotelic inflorescences 1-16-flowered, rachis $0-14 \mathrm{~cm}$ long, flowers subtended by scale leaves or leaves; anauxotelic inflorescences 1-3-flowered, rachis $0-0.5 \mathrm{~cm}$ long, flowers subtended by scale leaves. Pedicels 2-6 mm long, erect, sparsely to densely hairy. Tepals $12-13 \mathrm{~mm}$ long, acuminate to caudate, sparsely to moderately hairy, yellow. Anthers yellow. Ovary moderately hairy. Ovule(s) 1 or rarely 2 . Drupes green. 
DERIVATION OF EPITHET: Latin conjunctus, joined together, referring to the intermediate character of these populations between $P$. media and $P$. stradbrokensis.

FLOWERING PERIOD: January to February.

HАвгтAт: Dry to wet sclerophyll eucalypt forest on a variety of sedimentary and metamorphic substrates, from near sea level to at least $350 \mathrm{~m}$ altitude.

Distribution: Coastal ranges and valleys of New South Wales between the Bellinger and Manning Rivers (Figure 4).

CONSERVATION STATUS: not rare.

Notes: This taxon is a class that encompasses populations that are intermediate

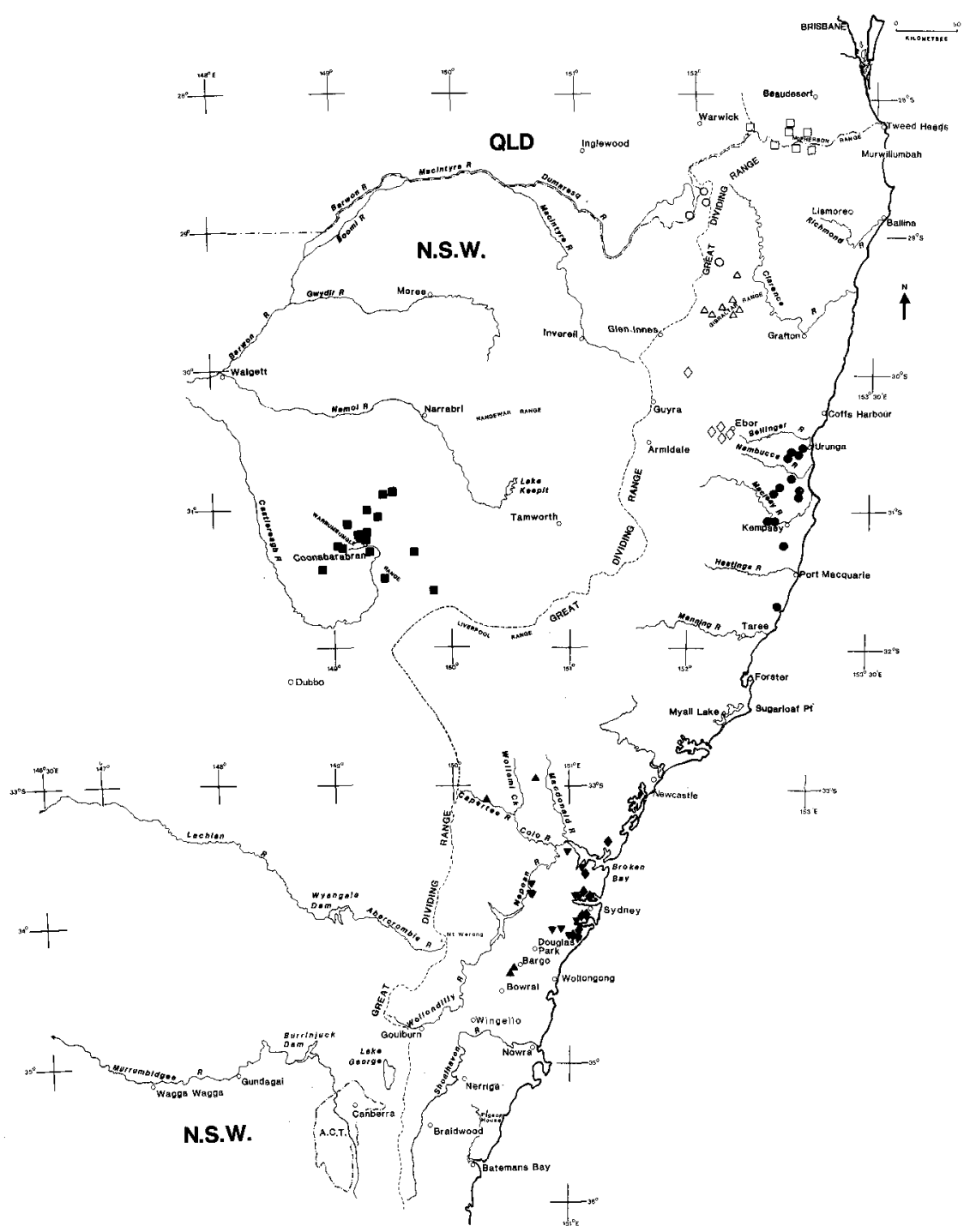

Figure 4. Distributions of Persoonia conjuncta (๑), P. cuspidifera (๘), P. daphnoides (O), P. hirsuta subsp. hirsuta $(\bullet), P$. hirsuta-evoluta intergrades $(\boldsymbol{\nabla}), P$. hirsuta subsp. evoluta $(\mathbf{(}), P$. procumbens $(\diamond), P$. rufa $(\triangle)$ and P. volcanica $(\square)$. 
between Persoonia media and $P$. stradbrokensis, occurring commonly in a quite large geographic area, between the distributions of those species. It might be suggested that the existence of these populations is inconsistent with the recognition of $P$. media and $P$. stradbrokensis as species and that perhaps a single species with three subspecies should be recognised. Such a classification would, however, be potentially misleading, since the detailed cladistic relationships between these taxa and their close relatives are quite unclear, and grouping them together would probably create a paraphyletic taxon. It seems best to name this class of populations as a 'species of convenience', at least until relationships within this group are better understood.

$P$. conjuncta apparently hybridises sporadically with $P$. linearis where they occur sympatrically.

Selected specimens (15): New South Wales: North Coast: Martells Road, $4.4 \mathrm{~km}$ W of Pacific

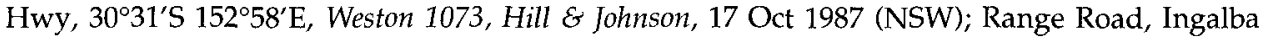
State Forest, $30^{\circ} 48^{\prime} \mathrm{S} 152^{\circ} 48^{\prime} \mathrm{E}$, Johnson 8705, 28 Jan 1983 (NSW); Pacific Hwy, $4.2 \mathrm{~km} \mathrm{~N}$ of Cooperabung Ck, $31^{\circ} 1^{\prime} \mathrm{S} 152^{\circ} 49^{\prime} \mathrm{E}$, Weston 1376-1377 \& Richards, 30 Jan 1989 (NSW); Pacific Hwy, between turnoff to Rossglen and Charlies Yard Rd, $31^{\circ} 40^{\prime} \mathrm{S} 152^{\circ} 44^{\prime} \mathrm{E}$, Weston $1378-1379 \mathcal{E}$ Richards, 30 Jan 1989 (NSW).

\section{Persoonia cuspidifera $L$. Johnson $\mathcal{E} P$. Weston, sp. nov.}

Folia anguste ad late spathulata, 1-2.0 $\mathrm{cm}$ longa, 1.5-5 mm lata, convexa, plusminusve incurva, valde scabra. Flores regulares. Antherae flavae, sine appendice. Ovarium glabrum.

Holotype: New South Wales: North Western Slopes: Newell Hwy, $4.1 \mathrm{~km}$ NNE of

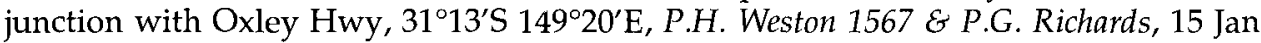
1990 (NSW). IsOTYPES: AD, BRI, CBG, K, MEL, MO, PERTH, RB.

$P$. rigida $\mathrm{R}$. Br. var. microphylla Benth., pro parte; non $P$. microphylla $\mathrm{R}$. Br. (Bentham 1870: 400).

Type citation: 'Blue Mountains, Caley; Castlereagh, C. Moore'. Syntrpe: Castlereagh River, near Belair, C. Moore, - (NSW).

[P. sp. D (aff. rigida) in Jacobs \& Pickard (1981: 182)]

Erect shrubs, $0.3-2 \mathrm{~m}$ high. Bark smooth. Hairs of moderate length, greyish to tawny (0.1-1.1 mm long), appressed to patent. Young branchlets moderately to densely hairy; internodes $0-10(-20) \mathrm{mm}$ long. Leaves alternate, narrowly to broadly spathulate, acuminate to mucronate, $1-2.0 \mathrm{~cm}$ long, $1.5-5 \mathrm{~mm}$ wide, convex, slightly to strongly incurved, spreading to suberect, not falcate, not pungent, concolorous, green, sparsely to moderately hairy when immature, glabrescent when mature, strongly papillose-scabrous; venation obscure. Inflorescences axillary to terminal, auxotelic, 125-flowered; rachis 0-7 cm long; flowers mostly subtended by leaves. Pedicels $2-5 \mathrm{~mm}$ long, erect, moderately hairy. Tepals $8-15 \mathrm{~mm}$ long, apiculate, moderately hairy, yellow marked with amroon on the outside, especially along the amrgins. Anthers yellow. Ovary glabrous. Ovule 1. Drupes green with purple stripes. Cotyledons 4-5.

DERIVATION OF EPITHET: Latin cuspidifera, bearing a cusp, referring to the leaf-shape.

FLOWERING PERIOD: November to March.

НАвітАт: Heathy and scrubby understorey of dry sclerophyll communities on sandstone. 
Distribution: The southern Pilliga Scrub and foothills of the Warrumbungle Mountains, New South Wales (Figure 4).

CONSERVATION STATUS: $3 \mathrm{~K}$.

Notes: $P$. cuspidifera most closely resembles its sister species, $P$. curvifolia, from which it is distinguished by its much broader, spathulate-cuspidate leaves. $P$. cuspidifera and $P$. curvifolia share one obvious synapomorphy: the abaxial surface of the tepals in both species is pigmented with dull dark red, restricted to the tepal-margins in some individuals, but covering the entire surface in others. These species apparently hybridise sporadically where they occur sympatrically in the Pilliga area.

$P$. cuspidifera apparently hybridises sporadically with $P$. sericea, a species with which it is frequently sympatric.

Selected SPECimens (21): New SOUtH WALES: North Western Slopes: Tummallallee [Timmallallie] Ck, c. 30 miles [48 km] NNE of Coonabarabran on Narrabri road, Johnson, 7 Nov 1951 (NSW 21006); 5 miles [8 km] N of Coonabarabran, along Newell Highway, Richards 18, 12 July 1966 (NSW ex CBG); 2 miles [3 km] N of Long Ridge, c. 22 miles [35 km] E of Coonabarabran, Johnson, 29 Sep 1968 (NSW 86877); Warrumbungle Mountains, Constable, 23 May 1948 (NSW 16586, K); Parish of Bomera, County Pottinger, Taylor, 25 Feb 1922 (NSW 21009).

\section{P. hirsuta Pers.}

(Persoon 1805: 118)

TYPE: None cited. Persoon's description, though brief, clearly applies to what is here taken as the type form of this species. He received his specimens from J.E. Smith. No type specimens have been found at $\mathrm{L}$.

Linkia hirsuta (Pers.) Kuntze (Kuntze 1891: 579)

P. arida Sieber ex Sprengel (Sprengel 1827: 45). Trpe CITATION: 'Sieb. ... Nov. Holl.'. SYNTYPES: (Sieber 55): B? n.V., BM, K, NY.

Sieber 55 is a mixed collection of at least two distinct elements, one of which is P. hirsuta subsp. hirsuta, while another is $P$. hirsuta subsp. evoluta.

P. hirsuta [var.] $\beta$ subovalis Endl. (Endlicher 1848: 81) (based on P. hirsuta $\beta$ R. Br. (Brown 1830: 13), which in turn was based on $P$. arida).

FLOWERING PERIOD: Mostly November to January but occasionally as early as September.

HABiтAT: Dry sclerophyll eucalypt woodland to forest, on sandy to stony soils derived from sandstone, from near sea-level to $600 \mathrm{~m}$ altitude.

Distribution: Patchily distributed in an area bounded by Putty, Glen Davis and Gosford, south to Royal National Park and Hill Top, in eastern New South Wales (Figure 4).

Notes: Geographic variation in P. hirsuta is clinal, from narrow-leaved populations in the east to broad-leaved populations in the west. Subsp. evoluta is arbitrarily distinguished from subsp. hirsuta by its broader, obtuse leaves with less prominently recurved margins. Specimens from the lower Blue Mountains and western suburbs of Sydney (and even some specimens from farther east) are intermediate between the extreme eastern and western forms.

The cladistic relationships of $P$. hirsuta are unclear, and it has no obvious close relatives. It is not known to hybridise with any other species. 


\section{Key to subspecies}

1 Leaves linear to narrow-oblong, acute, $0.75-1.5 \mathrm{~mm}$ wide, with revolute margins subsp. hirsuta

$1^{*}$ Leaves spathulate to elliptical or narrowly so, mostly obtuse, $1.5-5 \mathrm{~mm}$ wide with mostly recurved margins subsp. evoluta

\section{P. hirsuta subsp. hirsuta}

$P$. hirsuta [var.] $\alpha$ linearis Endl. (Endlicher 1848: 81) (based on a reference to P. hirsuta $\alpha$ R. Br. (Brown 1830: 13), which by implication is based on P. hirsuta Pers.).

[P. hirsuta subsp. A in Jacobs \& Pickard (1981: 181)]

Distribution: From Gosford to Royal National Park, within $20 \mathrm{~km}$ of the coast, below $300 \mathrm{~m}$ altitude (Figure 4 ).

Selected specimens (17): New South Wales: Central Coast: Gosford, Boorman, Jan 1903 (NSW 20894); Sir Edward Hallstrom Reserve, Cowan, Metcalf, - (NSW 94804); Roseville East, Johnson, 14 Dec 1952 (NSW 21404); North Head, Coveny, 26 Aug 1967 (NSW); [Royal] National Park, Hamilton, 9 Nov 1898 (NSW 21776).

P. hirsuta subsp. evoluta - subsp. hirsuta intergrades

Distribution: Maroota to Macquarie Fields, c. 15 to $65 \mathrm{~km}$ from the coast, below 300 $\mathrm{m}$ altitude (Figure 4).

Selected specimens (20): New South Wales: Central Coast: Maroota, Blakely \& Shiress, 15 Sep 1929 (NSW 20893); Glenbrook, Maiden, Nov 1914 (NSW 21768); 2 km from Windsor Rd along Annangrove Rd, Rouse Hill, Benson 2382 \& Keith, 18 Oct 1985 (NSW); East Hills Railway Station, Coveny 451, 4 Aug 1968 (NSW 112271); Long Point, Macquarie Fields, McBarron 14804, 28 Dec 1967 (NSW).

P. hirsuta subsp. evoluta L. Johnson $\mathcal{E}$ P. Weston, subsp. nov.

Differt a subspecie hirsuta foliis spathulatis ad ellipticis vel angustis, obtusis ad acutis, 1.5-5 mm latis, marginibus plerumque recurvis.

Holotype: New SOUTH W ALES: Central Coast: corner of Banksia and Wattle Streets, Hill Top, 34²1'S $150^{\circ} 29^{\prime} \mathrm{E}$, P.H. Weston 432 \& J. Dalby, 15 Jan 1985 (NSW). Isotypes: AD, B, BRI, CANB, HO, K, L, MEL, MO, NBG, PERTH, RSA.

P. hirsuta [var.] $\gamma$ spathulata Meissner (Meissner 1856: 337). TYPE CITATION: 'Sieber...n. 529!'. SYNTYPE: BM.

[P. hirsuta subsp. B in Jacobs \& Pickard (1981: 181)]

DERIVATION OF EPITHET: Latin evolutus, unrolled, referring to the broader leaves, in which the margins are not tightly revolute as they are in the type subspecies.

Distribution: Sporadically distributed in the Putty, Glen Davis and Hill Top districts, at 350-600 $\mathrm{m}$ altitude (Figure 4).

Selected SPECimens (11): New South Wales: Central Coast: E of Putty, Johnson, 20 Sep 1951 (NSW 17863); Green Gully, $1.7 \mathrm{~km} S$ of Glen Davis, 330.7'S 150 ${ }^{\circ} 16^{\prime} \mathrm{E}$, Crisp 2201 \& Telford, 25 Oct 1976 (NSW ex CBG); Balmoral [near Hill Top], Bingham, Nov 1896 (NSW 21765); Hill Top, Maiden, Jan 1896 (NSW 21766, AD, BRI, CBG, MEL, PERTH). 
Persoonia isophylla L. Johnson $\mathcal{E} P$. Weston, sp. nov.

Folia linearia, $1.2-3.0 \mathrm{~cm}$ longa, $0.5 \mathrm{~mm}$ lata, teretia, laevia. Inflorescentiae auxotelicae floribus saepissime in axillis foliorum evolutorum. Flores regulares. Antherae flavae, sine appendice. Ovarium glabrum.

Holotype: New South Wales: Central Coast: Peats Ridge-Kulnura road, $1.7 \mathrm{~km} \mathrm{~S}$ of Central Mangrove, $33^{\circ} 18^{\prime} \mathrm{S} 151^{\circ} 14^{\prime} \mathrm{E}$, P.H. Weston 1425 \& D.M. Weston, 26 Dec 1989 (NSW). ISOTYPES: AD, BRI, CBG, HO, K, MEL, MO, PERTH, RB.

[P. sp. A (aff. pinifolia) in Jacobs \& Pickard (1981: 182)]

Erect to spreading shrubs, $0.3-1.5 \mathrm{~m}$ high. Bark smooth. Hairs of moderate length (0.1$1.4 \mathrm{~mm}$ long), greyish, appressed to antrorse. Young branchlets sparsely hairy; internodes (0-)0.5-4(-15) mm long. Leaves alternate, linear, acuminate, $1.2-3.0 \mathrm{~cm}$ long, 0.5 $\mathrm{mm}$ wide, terete but grooved underneath when dried, often recurved, spreading, not falcate, not pungent, concolorous, green, glabrous to sparsely hairy when immature, glabrescent when mature, smooth; venation obscure. Inflorescences mostly subterminal to terminal, auxotelic, (1-)10-70-flowered; rachis $0.5-9 \mathrm{~cm}$ long; flowers mostly subtended by leaves. Pedicels $0-1.5 \mathrm{~mm}$ long, erect to spreading, glabrous to moderately hairy. Tepals 7-8 mm long, apiculate, glabrous to sparsely hairy, yellow. Anthers yellow. Ovary glabrous. Ovule 1. Drupes green and usually suffused with reddish purple. Cotyledons 5.

DERIVATION OF EPITHET: Greek isos, equal, and phyllon, a leaf; referring to the inflorescences in which the flowers are subtended by full-sized leaves, in contrast to the inflorescences of $P$. pinifolia, in which the flowers are subtended by reduced leaves.

FLOWERING PERIOD: January to July.

HaBiTAT: Heath to dry sclerophyll eucalypt forest on sandy or stony soils derived from Hawkesbury Sandstone, from near sea-level to $250 \mathrm{~m}$ altitude.

Distribution: Central Coast of New South Wales, from the Gosford-Kulnura district to the Manly district. (Figure 5).

Conservation Status: not rare.

Notes: $P$. isophylla closely resembles $P$. pinifolia, and it seems most likely that they are sister species, sharing the following synapomorphies: linear, terete leaves, the potential to produce acrotonic as well as basitonic inflorescences, many-flowered inflorescences. These species have been confused in the past but $P$. isophylla is distinguished by its shorter, usually brighter green leaves, and its consistently auxotelic inflorescences in which the great majority of flowers are subtended by full-sized leaves. They grow sympatrically south of the Hawkesbury River but hybrids between them seem to be very rare; no other hybrids of $P$. isophylla have been recorded. In general, $P$. isophylla grows in more heathy sites than $P$. pinifolia.

Selected specimens (24): New South Wales: Central Coast: top of Judge Dowling Range, c. 3 miles [4.6 km] SW of Bucketty, McGillivray 1223, 5 July 1965 (NSW, CBG, MEL); Kulnura, 3314'S $151^{\circ} 13^{\prime}$ E, Coveny 5849, Hind \& Hancock, 23 Nov 1974 (NSW, AD, BRI, CBG, MEL, PERTH); near Empire Bay turn-off on Gosford-Kilcare road, McKern, 20 Apr 1958 (NSW 43383, CBG, MEL); above 'The Duckhole', near head of McCarrs Ck, W of Church Point, Johnson, 20 Feb 1952 (NSW 20991, CBG); Deep Creek, Narrabeen, Coveny, 15 Oct 1966 (NSW, CBG); northern end of Manly Dam, 334ㄴ $151^{\circ} 14^{\prime} \mathrm{E}$, Taylor 290 \& Coveny, 2 Oct 1984 (NSW, MEL, PERTH).

Persoonia katerae $P$. Weston $\mathcal{E}$ L. Johnson, sp. nov.

Cortex pro parte maxima laevis sed basin versus subtiliter fissus. Pili breves, griseusculi, adpressi vel antrorsi. Folia anguste elliptica ad oblanceolata, 6-17 cm longa, 
8-22 mm lata, marginibus aliquantulo recurvis, recta falcatave, viridia sed in sicco nigrescentia. Flores regulares. Antherae flavae, sine appendice. Ovarium glabrum. Ovula 2.

Holotype: New South Wales: North Coast: Boomerang Drive, $1.2 \mathrm{~km}$ N of Headland Rd, $0.2 \mathrm{~km}$ W of Boomerang Beach, 32 $20^{\prime} 15^{\prime \prime S} 152^{\circ} 32^{\prime} 30^{\prime \prime}$, P.H. Weston 1124 \& P.G. Richards, 28 Jan 1988 (NSW). IsOTYPEs: BRI, CBG, K, MEL, MO.

Erect shrubs or small trees, $2.5-9 \mathrm{~m}$ high. Bark mostly smooth but rough and finely fissured at base. Hairs short (mostly $0.05-0.5 \mathrm{~mm}$ long), greyish, appressed to antrorse. Young branchlets moderately hairy; internodes $0-45(-65) \mathrm{mm}$ long. Leaves alternate, narrow-elliptical to oblanceolate, acute to acuminate, 6-17 cm long, 8-22

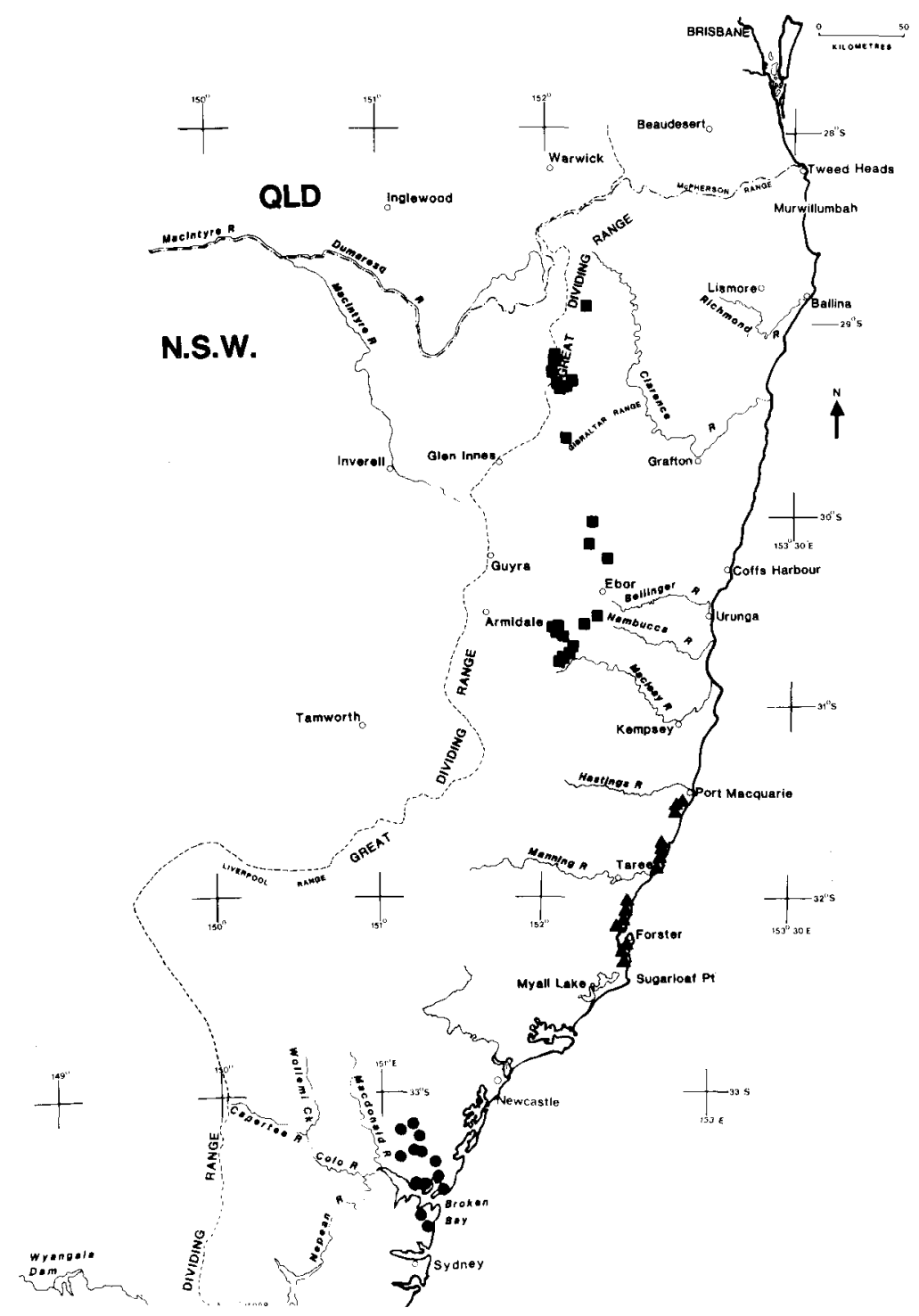

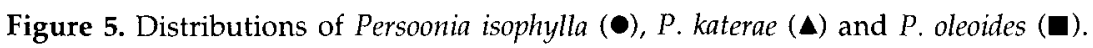


mm wide, flat, with slightly recurved margins, spreading to suberect, not falcate to falcate, twisted through 0-0.25 turns, not pungent, concolorous, green but turning black on natural drying, glabrous to sparsely hairy when immature (but much denser on margins), glabrescent when mature, smooth; venation brochidodromous, usually evident on both surfaces. Inflorescences mostly subterminal to terminal, auxotelic, (3-)6-22-flowered; rachis (1-)3-16 cm long; flowers mostly subtended by leaves. Pedicels $35 \mathrm{~mm}$ long, erect, moderately hairy. Tepals 9-12 mm long, acute to acuminate, moderately hairy, yellow. Anthers yellow. Ovary glabrous. Ovules 2. Drupes green or green suffused with reddish purple.

DeRIVATION OF EPITHET: In honour of Mrs Penelope Kater, who indirectly drew our attention to this taxon. She has worked as a volunteer, at the National Herbarium of New South Wales, since 1985, assisting in accummulating and curating herbarium specimens of Proteaceous seedlings.

FLOWERING PERIOD: January to February.

HABrTAT: Heath to dry sclerophyll forest, usually in association with Banksia integrifolia or Eucalyptus pilularis, exclusively on stabilised coastal sand dunes, at altitudes less than $20 \mathrm{~m}$.

DisTRIBUTION: Between Lake Cathie and Smiths Lake of north coastal New South Wales (Figure 5).

CONSERVATION STATUS: not rare.

Notes: Surprisingly, this handsome species seems never to have been collected before 1987, although it is common (and in some localities dominant) over quite a wide, accessible area. It most closely resembles $P$. media, $P$. conjuncta, and $P$. stradbrokensis, from which it is distinguished by consistently having 2 ovules per carpel, leaves that turn black on natural drying (check fallen leaves in the field), and in having appressed to antrorse, short, greyish hairs that are moderately dense on the branchlets.

$P$. katerae and P. lanceolata often grow sympatrically and occasionally hybridise.

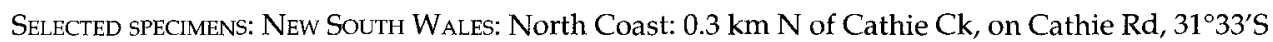
$152^{\circ} 51^{\prime} \mathrm{E}$, Weston 1145-1147 \& Richards, 29 Jan 1988 (NSW); Crowdy Head - Diamond Head track, $7 \mathrm{~km}$ directly $\mathrm{N}$ of Crowdy Head, Crowdy Head National Park, $31^{\circ} 46^{\prime} \mathrm{S} 152^{\circ} 31^{\prime} \mathrm{E}$, Weston 1142-1144 \& Richards, 29 Jan 1988 (NSW); road to Tuncurry tip, $0.1 \mathrm{~km}$ NE of Tuncurry Rd, $32^{\circ} 08^{\prime} \mathrm{S} 152^{\circ} 30^{\prime} \mathrm{E}$, Weston 1130-1132 \& Richards, 28 Jan 1988 (NSW); The Lakes Way, Tiona, $32^{\circ} 18^{\prime} \mathrm{S}$ $152^{\circ} 31^{\prime} \mathrm{E}$, Weston 1117, 5 Nov 1987 (BRI, CBG, NSW).

Persoonia laurina Pers.

(Persoon 1805: 118)

TYPE: None cited. Persoon's description, though brief, is quite sufficient to characterise the species amongst 'Port Jackson' plants known at that date. He received his specimens from J.E. Smith. No type specimens have been found at $\mathrm{L}$.

FLOWERING PERIOD: November to January.

HABITAT: Dry sclerophyll woodland to forest, usually on sandy to stony soils derived from sandstone, or occasionally on sandy alluvium or granite or metasediments, at altitudes from near sea-level to $1200 \mathrm{~m}$.

Distribution: Central-eastern New South Wales, from Port Stephens south to Conjola on the coast and from the Capertee River to the southern Budawang Ranges on the tablelands. 
Notes: $P$. laurina seems to be a clade characterised by its style, which becomes reflexed in fruit. It apparently forms a clade with $P$. confertiflora, characterised by consistently subopposite to opposite leaves, and exclusively anauxotelic inflorescences. The sister species of this clade seems to be $P$. silvatica.

No hybrids of $P$. laurina are known, despite its frequent sympatric occurrence with many other species of Persoonia.

Three parapatric subspecific races within $P$. laurina can be diagnosed on the basis of two characters: the presence or absence of scabrous papillae on the mature leaves and a densely hairy or glabrous ovary.

\section{Key to subspecies}

1 Ovary densely hairy; mature leaves smooth or scabrous; style strongly reflexed on mature drupe

2 Mature leaves smooth subsp. laurina

2* Mature leaves scabrous ubsp. intermedia

$1^{*}$ Ovary glabrous; mature leaves scabrous; style reflexed on mature drupe subsp. leiogyna

\section{P. laurina subsp. laurina}

P. ferruginea Smith (Smith 1806: 47, t. 83)

Type citation: 'near Port Jackson'.

TYPE: LINN (n.v.).

Linkia ferruginea (Smith) Kuntze (Kuntze 1891: 579)

P. maidenii Gandoger (Gandoger 1919: 227). TyPe CITATION: 'Australia. N.S.Wales ad Port Jackson. Maiden.' Holotype: Port Jackson District, J.H. Maiden, Jan 1893 (LYON).

P. monticola Gandoger (Gandoger 1919: 227) TYPE CITATION: 'Australia. N.S.Wales in Monte Victoria. Walter.' HolOTYPE: Mount Victoria, Walter, Dec 1886 (LYON).

[P. laurina subsp. A in Jacobs \& Pickard (1981: 181)]

Distribution: From the Bulahdelah district to the Georges River on the coast and the Capertee River to Coxs River - Lake Burragorang on the tablelands (Figure 6).

CONSERVATION STATUS: not rare.

Selected Specimens (56): New South Wales: North Coast: 2 miles [3 km] W of Karuah, Johnson, 12 Oct 1953 (NSW 26376). Central Coast: Maroota, Blakely \& Shiress, 15 Sep 1929 (NSW 21792); Agnes Banks, Benson 1034, 5 Dec 1974 (NSW); Springwood, Cross, Mar 1934 (NSW); Hurstville, Camfield, Dec 1896 (NSW 21803). Central Tablelands: Excelsior, Boorman, Jan 1914 (NSW 20950); Evans Lookout, $33^{\circ} 39^{\prime} \mathrm{S} 150^{\circ} 20^{\prime} \mathrm{E}$, Weston 1274 \& Catling, 31 Oct 1988 (NSW).

\section{P. laurina subsp. intermedia L. Johnson \& P. Weston, subsp. nov.}

Inter subspeciem laurinam et subspeciem leiogynam; foliis modice scabris et ovario dense piloso distinguitur.

Holotype: New South Wales: Central Coast: Banksia St, Hill Top, 3421'S 150 29'E, P.H. Weston 1419 \& S. Krauss, 19 Dec 1989 (NSW). Isotypes: AD, BRI, CBG, HO, K, MEL, MO, PERTH, RB.

[P. laurina subsp. B in Jacobs \& Pickard (1981: 181)] 
DeRIVATION OF EPITHET: Latin inter, between, and medius, middle, referring to the combination of characters and the partly intermediate area of occurrence.

Distribution: From the upper Georges River to Bowral and the Wombeyan district (Figure 6).

CONSERVATION STATUS: not rare.

SeleCted sPeCtMmens (21): NeW SOUTH Wales: Central Coast: 3 miles [ $5 \mathrm{~km}$ ] E of Leumeah, Johnson, 6 Nov 1948 (NSW 20730); Yerrinbool, Johnson, 15 Apr 1951 (NSW 21808). Central Tablelands: The Gib [Mt Gibraltar], Bowral, Rupp, 20 Nov 1945 (NSW 864); Richlands to Wombeyan Caves, Moore 2642, 13 Oct 1953 (NSW).

P. laurina subsp. leiogyna L. Johnson $\mathcal{E}$ P. Weston, subsp. nov.

Inter subspeciebus combinatione foliorum scabrorum et ovarii glabri distinguitur.

Holotype: New South Wales: Central Tablelands: Wingello, J.L. Boorman, Dec 1917 (NSW 21826).

[P. laurina subsp. C in Jacobs \& Pickard (1981: 181)]

DERIVATION OF EPITHET: Greek leios, smooth, and gyne, a woman, referring to the glabrous ovary.

Distribution: From the Jenolan Caves district to the southern Budawang Range and Conjola (Figure 6).

CONSERVATION STATUS: not rare.

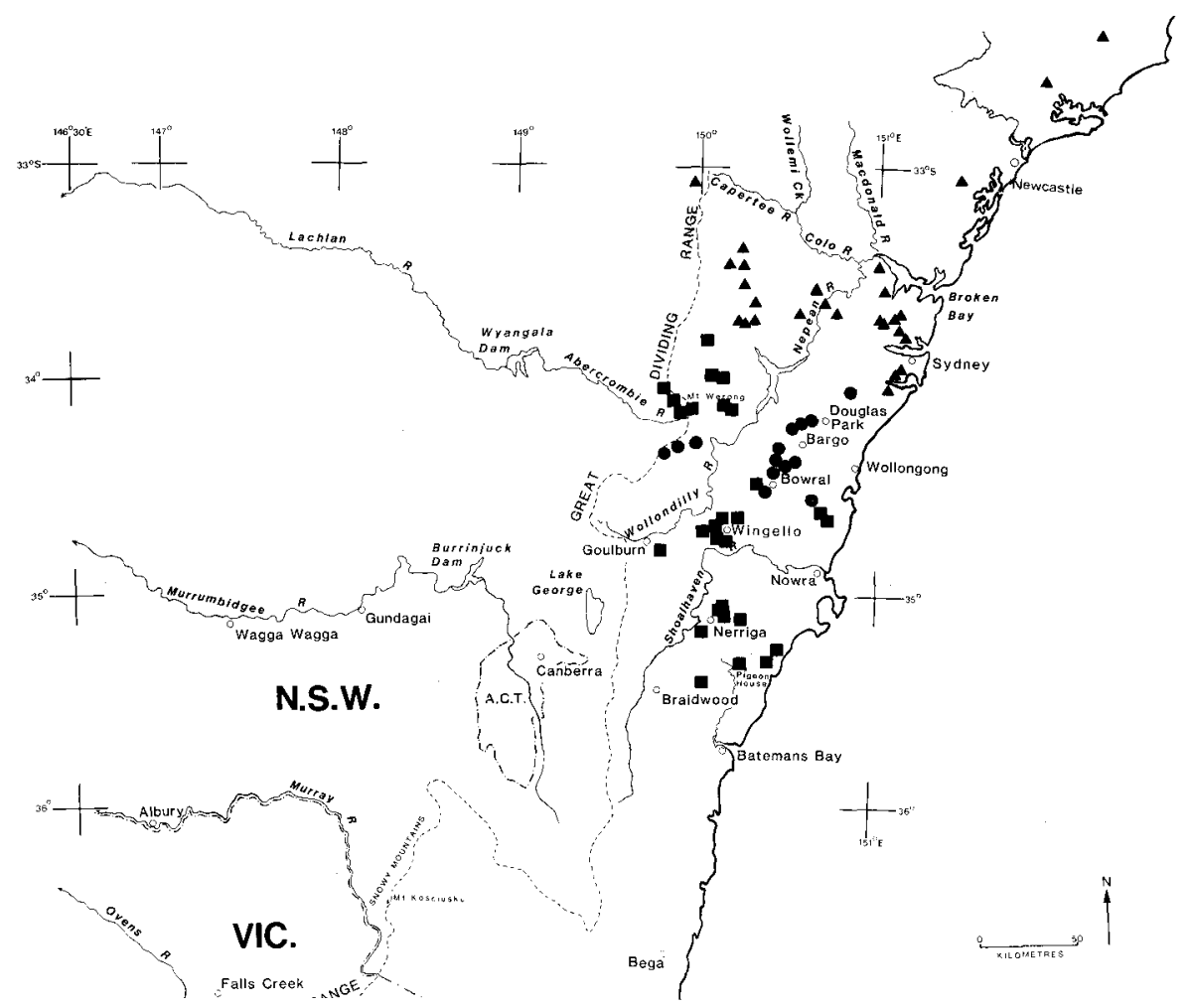

Figure 6. Distribution of Persoonia laurina: subsp. laurina (४), subsp. intermedia $(\bullet)$ and subsp. leiogyna $(\mathbf{\square})$. 
Notes: This taxon is distinguished from both of the other subspecies by its glabrous ovary. It is further distinguished from subsp. laurina, and also from $P$. silvatica and $P$. confertiflora, by its papillose-scabrous mature leaves.

Selected sPecimens (35): New South Wales: South Coast: Conjola, Heron, Nov 1898 (NSW 21831). Central Tablelands: Ruby Creek Falls, Mt Werong State Forest, $34^{\circ} 05^{\prime} \mathrm{S} 149^{\circ} 56^{\prime} \mathrm{E}$, Coveny 12159 , Bishop \& Makinson, 18 Sep 1985 (NSW, B, DAR, K, PERTH); Jamberoo Mtn Rd, Carrington Falls, 34 37'S 150 41'E, Weston 1391 \& Bishop, 7 Apr 1989 (NSW). Southern Tablelands: 8 km E of Nerriga along Nerriga - Nowra road, $35^{\circ} 05^{\prime} \mathrm{S} 150^{\circ} 08^{\prime} \mathrm{E}$, Pullen 10.212, 2 Dec 1975 (NSW ex CANB); $16 \mathrm{~km}$ NNE of Mongarlowe, Johnson 7247, 18 Aug 1971 (NSW).

\section{Persoonia oleoides L. Johnson $\mathcal{E}$ P. Weston, sp. nov.}

Frutices multicaules erecti vel decumbentes. Ramuli novelli modice ad dense pilosi. Folia variantia: oblonga, elliptica, ovata, obovata, vel anguste rare late spathulata, 2-6(-9) cm longa, 4-15(-26) $\mathrm{mm}$ lata, marginibus plusminusve recurvis, concoloria vel subdiscoloria. Flores regulares. Tepala modice pilosi. Antherae flavae, sine appendice. Ovarium glabrum vel rare pilosiusculum.

Holotype: New South Wales: Northern Tablelands: Styx River Forest Way, 1.9 km NE of Armidale - Kempsey road, 30³6'30"S 152 $11^{\prime} 45^{\prime \prime E}$, P.G. Richards 84 E P.H. Weston, 31 Jan 1988 (NSW). IsOTYPES: AD, BRI, CBG, K, MEL, MO, PERTH, RB.

Erect to decumbent shrubs, $0.2-1.0 \mathrm{~m}$ high. Bark smooth. Hairs of short to moderate length $(0.1-0.9 \mathrm{~mm}$ long), greyish to ferruginous, appressed to antrorse. Young branchlets moderately to densely hairy; internodes $0-22(-34) \mathrm{mm}$ long. Leaves alternate, oblong to elliptical to ovate to obovate to spathulate or narrowly or rarely broadly so, acuminate to mucronate, $2-6(-9) \mathrm{cm}$ long, $4-15(-26) \mathrm{mm}$ wide, flat, with recurved margins (sometimes only slightly so), sometimes incurved, spreading to suberect, not falcate, not pungent, concolorous to slightly discolorous, green, sparsely hairy when immature (but denser on margins), glabrescent to sparsely so on adaxial surface when mature, smooth to slightly scaberulous; venation brochidodromous, obscure to evident on both surfaces. Inflorescences axillary to terminal, anauxotelic $(0-92 \%)$ or auxotelic (8-100\%); auxotelic inflorescences 1-25-flowered, rachis $0-13 \mathrm{~cm}$ long, flowers subtended by scale leaves or leaves; anauxotelic inflorescences $1-3(-15)$ -flowered, rachis $0-1.0(-3.5) \mathrm{cm}$ long, flowers subtended by scale leaves. Pedicels 1-3 (-5) $\mathrm{mm}$ long, erect, moderately to densely (or rarely sparsely) hairy. Tepals 10-15 mm long, apiculate to shortly caudate, moderately hairy, yellow. Anthers yellow. Ovary glabrous or rarely sparsely hairy. Ovule 1. Drupes green or green with purple stripes or rarely entirely reddish purple.

DERIVATION OF EPTTHET: Latin olea, olive (i.e. Olea europaea, the common olive), with latinised Greek suffix -oides, resembling, referring to the shape of the leaves in many individuals.

FLOWERING PERIOD: January to February.

НАвітат: Dry to wet sclerophyll eucalypt forest, on various metamorphic and igneous substrates, common on the eastern side of the Northern Tablelands of New South Wales to an altitude of $1300 \mathrm{~m}$, but also occurring occasionally down to the foot of the eastern escarpment of the tablelands, as low as $190 \mathrm{~m}$ altitude.

Distribution: Between the upper Clarence River and the upper Macleay River. Absent from, although occurring just west of, the highly siliceous granite country of the Gibraltar Range (Figure 5).

CONSERVATION STATUS: not rare. 
Notes: This species shows remarkable variability in the shape and size of its leaves, and in inflorescence behaviour (individuals can have predominantly auxotelic or anauxotelic inflorescences) but is relatively stable in other characters such as habit. Leaf length seems to be negatively correlated with altitude, and populations from low altitudes tend to be more variable in leaf morphology than those from the tablelands.

$P$. oleoides forms narrow hybrid zones with $P$. cornifolia, which only occurs to the west of $P$. oleoides. One such zone is found just west of the Styx River bridge on the Armidale-Kempsey road, where, over a distance of perhaps $300 \mathrm{~m}$, plants with apparently random combinations of characters of both parent-species occur. $P$. oleoides often grows sympatrically with $P$. media but these species apperently seldom hybridise.

Until recently we had thought that specimens of $P$. oleoides might be hybrids between $P$. cornifolia and $P$. procumbens. They often appear to be morphologically intermediate between these species and the sympatric occurrence of $P$. procumbens with hybrid swarms of $P$. oleoides and $P$. cornifolia seemed to corroborate this idea. However, populations of $P$. oleoides occur in many localities without any other species of Persoonia.

SELECTED SPECIMENS (46): New SOUTH WALES: North Coast: Bruxner Hwy at Crooked Creek, $28^{\circ} 55^{\prime} \mathrm{S}$ $152^{\circ} 17^{\prime} \mathrm{E}$, Weston 1335-1337 \& Richards, 12 Jan 1989 (NSW); $3.8 \mathrm{~km}$ N of Georges Creek bridge, Georges Creek Nature Reserve, 30 $43^{\prime} \mathrm{S} 152^{\circ} 47^{\prime} \mathrm{E}$, Richards 58-60 \& Weston, 31 Jan 1988 (NSW). Northern Tablelands: Spirabo Firetrail, at gate $1.8 \mathrm{~km} \mathrm{~N}$ of junction with Upper Rocky River Trail, Spirabo State Forest, $2^{\circ} 18^{\prime} \mathrm{S} 152^{\circ} 07^{\prime} \mathrm{E}$, Weston 1327-1328 \& Richards, 25 Jan 1989 (NSW);

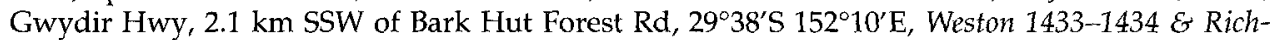
ards, 2 Jan 1990 (NSW); Chaelundi Mtn, hill on E side of road, Chaelundi State Forest, $30^{\circ} 04^{\prime} \mathrm{S}$ $152^{\circ} 21^{\prime} \mathrm{E}$, Hill 2737, Johnson \& Weston, 18 Oct 1987 (NSW, BRI, CBG); c. 1 mile $[1.6 \mathrm{~km}] \mathrm{W}$ of Point Lookout, J.B. Williams, 12 Feb 1966 (NSW ex UNE).

\section{Persoonia procumbens L. Johnson \& P. Weston, sp. nov.}

Frutices prostrati. Pili ferruginei. Folia alterna, saepissime obovata spathulatave, $1.5-$ $3.6 \mathrm{~cm}$ longa, 4-17 mm lata, concoloria. Flores regulares. Pedicelli erecti. Tepala modice pilosa. Antherae flavae, sine appendice. Ovarium glabrum.

Holotype: New SOUTH Wales: Northern Tablelands: Point Lookout road, $0.7 \mathrm{~km}$ E of Armidale-Ebor road, $30^{\circ} 29^{\prime} \mathrm{S} 152^{\circ} 18^{\prime} \mathrm{E}$, P.G. Richards 92 \& P.H. Weston, 1 Feb 1988 (NSW). IsOTYPES: AD, BRI, CBG, K, MEL, MO, PERTH, RB.

[P. prostrata subsp. C in Jacobs \& Pickard (1981: 182)]

Prostrate shrubs, to $0.1 \mathrm{~m}$ high. Bark not well-developed. Hairs of short to moderate length (0.1-0.6 $\mathrm{mm}$ long), ferruginous, appressed to antrorse. Young branchlets moderately to densely hairy; internodes $0-12(-22) \mathrm{mm}$ long. Leaves alternate, mostly obovate to spathulate to cuneate, mostly acuminate to mucronate or less frequently acute to obtuse or emarginate, $1.5-3.6 \mathrm{~cm}$ long, 4-17 mm wide, flat, with slightly recurved margins, suberect, not falcate, twisted through 0-0.25 turns, not pungent, concolorous, green, sparsely hairy when immature, glabrescent when mature, smooth; venation brochidodromous, obscure to faintly evident. Inflorescences axillary to terminal, anauxotelic $(0-50 \%)$ or auxotelic (50-100\%); auxotelic inflorescences 1-6 -flowered, rachis 0-2 cm long, flowers subtended by scale leaves or leaves; anauxotelic inflorescences 1-3-flowered, rachis $0-0.1 \mathrm{~cm}$ long, flowers subtended by scale leaves. Pedicels $1.5-3 \mathrm{~mm}$ long, erect, moderately to densely hairy. Tepals 7-9 mm long, apiculate, sparsely hairy, yellow. Anthers yellow. Ovary glabrous. Ovule(s) 1 or rarely 2. Drupes green. Cotyledons 4. 
DERIVATION OF EPITHET: Latin procumbens, lying forward, referring to the habit.

FLOWERING PERIOD: December to February.

HABITAT: Dry sclerophyll eucalypt woodland to forest on sandy to clayey soil derived from granite (adamellite or leucoadamellite), at 1200 to $1500 \mathrm{~m}$ altitude.

Distribution: Backwater and Round Mountain areas, New England (Figure 4).

CONSERVATION STATUS: 2RC-.

Notes: $P$. procumbens resembles $P$. daphnoides (q.v.) very closely, differing only in the darker pigmentation of the hairs (greyish to tawny in $P$. daphnoides), its less densely hairy tepals (moderately hairy in P. daphnoides), smaller flowers (tepals 9-10 $\mathrm{mm}$ long in $P$. daphnoides) and slightly fleshier leaves (venation usually evident on both surfaces in $P$. daphnoides). These species are probably sister-species, united by a synapomorphy of prostrate habit. Together they most closely resemble $P$. oleoides, differing from it in their prostrate habit and smaller flowers.

We had originally followed Bentham (1870) in including $P$. procumbens and $P$. daphnoides in $P$. prostrata, as subspecies $C$ and $B$ respectively, in Jacobs \& Pickard (1981). The type specimen of P. prostrata (from Fraser Island, Queensland), however, differs from these two species in a number of characters, including its thicker stems, more coriaceous, larger, mostly elliptical leaves and densely hairy ovary (see also notes on $P$. prostrata and $P$. stradbrokensis, below).

$P$. procumbens occurs sympatrically with $P$. oleoides and $P$. cornifolia but appears not to hybridise with either species.

Selected Specimens (17): New South Wales: Northern Tablelands: Pheasant Mtn, c. $2 \mathrm{~km}$ NE of Backwater, $30^{\circ} 04^{\prime} \mathrm{S} 151^{\circ} 53^{\prime} \mathrm{E}$, Telford 8984 \& Butler, 20 Jan 1983 (NSW ex CBG); Biscuit Creek, 7.5 miles [12 km] NW of Ebor [on Guyra road], Ford 10 Jan 1958 (NSW 43159); Snowy Range, 1 km SE of Cathedral Rock, Cathedral Rock National Park, 30 $27^{\circ} \mathrm{S} 152^{\circ} 16^{\prime} \mathrm{E}$, Telford 10777, 2 Jan 1989 (NSW ex CBG); $9.5 \mathrm{~km} \mathrm{SW}$ of Ebor, on the Armidale - Grafton road, Coventy 2278, 5 Oct 1969 (NSW).

Persoonia rufa L. Johnson $\mathcal{E}$ P. Weston, sp. nov.

Pili ferruginei. Ramuli novelli modice vel dense pilosi. Folia elliptica vel late elliptica, 3 $-8 \mathrm{~cm}$ longa, 10-25 mm lata, subdiscoloria, scabra. Flores regulares. Tepala modice ad dense pilosi. Antherae flavae, sine appendice. Ovarium dense pilosum. Ovulum 1.

HolotyPE: NEw SOUTH WaLEs: Northern Tablelands: Gwydir Hwy, $4.3 \mathrm{~km}$ NE of turnoff to Raspberry Lookout, $29^{\circ} 32^{\prime} \mathrm{S} 152^{\circ} 17^{\prime} \mathrm{E}$, P.H. Weston 1428 \& P.G. Richards, 2 Jan 1990 (NSW). ISOTYPES: AD, BRI, CBG, K, MEL, MO, PERTH, RB.

[P. cornifolia subsp. C in Jacobs \& Pickard (1981: 181)]

Erect to spreading shrubs, 1-2.5 m high. Bark smooth. Hairs of moderate length (0.1-1.2 mm long), tawny to ferruginous, appressed to patent. Young branchlets moderately to densely hairy; internodes $0-35(-55) \mathrm{mm}$ long. Leaves alternate, elliptical to broad-elliptical, acuminate to mucronate, 3-8 cm long, 10-25 mm wide, flat, with recurved margins, sometimes slightly incurved, suberect, not falcate, twisted through $0-0.25$ turns, not pungent, slightly discolorous, green, moderately hairy when immature, glabrescent to moderately so when mature, scabrous; venation brochidodromous, obscure to evident (more prominent on adaxial surface). Inflorescences axillary to terminal, anauxotelic (10-95\%) or auxotelic (5-90\%); auxotelic inflorescences 1-12-flowered, rachis $0-11 \mathrm{~cm}$ long, flowers mostly subtended by leaves; anauxotelic inflorescences $1-3(-6)$-flowered, rachis $0-0.5(-1.5) \mathrm{cm}$ long, flowers subtended by scale leaves. Pedicels 1-3 mm long, erect, moderately to densely hairy. Tepals 10-14 mm long, 
caudate, moderately to densely hairy, yellow. Anthers yellow. Ovary densely hairy. Ovule 1. Drupes green or green with purple stripes. Cotyledons 4.

DERIVATION OF EPITHET: Latin rufus, red or reddish, referring to the ferruginous hairs of the young branchlets.

FLOWERING PERIOD: December to February.

НАвітAт: Heath to dry sclerophyll eucalypt forest, on stony or sandy to loamy soils derived from granite.

Distribution: Restricted to the Gibraltar Range, north-eastern New South Wales (Figure 4).

CONSERVATION STATUS: 2RCa.

Notes: $P$. rufa most closely resembles $P$. cornifolia and $P$. oleoides. It differs from the former species in the ferruginous colour of the hairs of the young branchlets and flowers, and its more strongly hairy-scabrous, more markedly discolorous leaves. It differs from $P$. oleoides in being a larger shrub, in its usually longer, more ferruginous hairs, its usually more scabrous leaves and its densely hairy ovary. Previously, one of us (LJ) had treated P. rufa as a subspecies of $P$. cornifolia (subsp. C in Jacobs \& Pickard 1981). However, since P. rufa does not seem to intergrade with any other taxon, and the cladistic relationships in this group remain obscure, it seems more appropriate to name $P$. rufa at specific rank.

P. rufa does not grow with any other species of Persoonia.

Selected SPECIMENS (8): NeW SOUTH WALEs: Northern Tablelands: southern end of Washpool State Forest, Johnson \& McGillioray 2426, 20 Sep 1966 (NSW, AD, BRI, CBG, MEL); Mulligans Hut, Gibraltar Range National Park, Coveny 2232, 3 Oct 1969 (NSW, CBG); Gibraltar Range National Park, $62 \mathrm{~km}$ ENE of Glen Innes, $2^{\circ} 32^{\prime} \mathrm{S} 152^{\circ} 20^{\prime} \mathrm{E}$, Coveny 5685 \& Lander, 3 Oct 1974 (NSW, B, K, PERTH, RSA); Gwydir Hwy, $0.8 \mathrm{~km}$ E of Raspberry Lookout turnoff, Gibraltar Range National Park, $29^{\circ} 33^{\prime} \mathrm{S} 152^{\circ} 16^{\prime} \mathrm{E}$, Richards 103 \& Weston, 1 Feb 1988 (NSW).

\section{Persoonia volcanica $P$. Weston $\mathcal{E}$ L. Johnson, sp. nov.}

Frutices erecti $1.8-6 \mathrm{~m}$ alti. Cortex laevis. Pili adpressi vel plusminusve patentes. Ramuli novelli modice pilosi. Folia variantia: lineari-lanceolata, anguste lanceolata, lineari-elliptica, anguste elliptica, lineari-oblonga vel anguste oblonga, 4-9 cm longa, 5-10(-15) mm lata. Flores regulares. Tepala pilosiuscula. Antherae flavae, sine appendice. Ovarium glabrum.

Holotype: New South WALEs: North Coast: Mt Lindesay Hwy, $12.0 \mathrm{~km} \mathrm{NE}$ of Woodenbong, $28^{\circ} 20^{\prime} \mathrm{S} 152^{\circ} 40^{\prime} \mathrm{E}$, P.H. Weston 1353 \& P.G. Richards, 27 Jan 1989 (NSW). IsOTYPES: AD, BRI, CBG, K, MEL, MO, NSW, PERTH, RB.

Erect shrubs, 1.8-6 m high. Bark smooth. Hairs of short to moderate length (0.05-0.6 $(-0.9) \mathrm{mm}$ long), greyish to ferruginous, appressed to patent. Young branchlets moderately hairy; internodes $(0-) 2-20(-40) \mathrm{mm}$ long. Leaves alternate, linearly to narrowly ovate to elliptical to oblong, acute to acuminate, 4-9 cm long, 5-10(-15) mm wide, flat, with recurved margins, spreading to suberect, not falcate or occasionally slightly falcate, not pungent, concolorous to strongly discolorous, green, sparsely to moderately hairy when immature, sparsely so to glabrescent when mature, smooth to slightly scaberulous; venation brochidodromous, obscure to faintly evident on both surfaces. Inflorescences axillary to terminal, usually auxotelic (rarely only 60\%); auxotelic inflorescences $1-15(-20)$-flowered, rachis $0-8(-18) \mathrm{cm}$ long, flowers subtended by scale leaves or leaves; anauxotelic inflorescences 1-3-flowered, rachis $0-0.7 \mathrm{~mm}$ long, flowers subtended by scale leaves. Pedicels $1.5-5(-8) \mathrm{mm}$ long, erect, moderately hairy. 
Tepals 9-13 mm long, shortly caudate, moderately hairy, yellow. Anthers yellow. Ovary glabrous. Ovule 1. Drupes green.

DERIVATION OF EPITHET: Neo-Latin volcanicus, volcanic, from Latin Volcanus, the Roman god of fire, referring to the substrate on which the species usually occurs.

FLoWERING PERIOD: Mostly December to February, but sometimes as late as May.

HАВітAт: Dry sclerophyll forest to rainforest margins in wet sclerophyll forest, usually on volcanic but sometimes on sedimentary substrates, at 500 to $1000 \mathrm{~m}$ altitude.

Distribution: McPherson Range on the New South Wales - Queensland border and nearby mountains between Wilsons Peak and Levers Plateau (Figure 4).

CONSERVATION STATUS: 2RC-.

Notes: This species has in the past been treated as a form, or unnamed infraspecific taxon, of $P$. media (see e.g. Stanley \& Ross 1986, as $P$. attenuata). It differs from that species in its mostly antrorse to patent hairs, which generally occur more densely, its leaves, which are smaller on average, its usually shorter pedicels, and its bark, which is smooth to the base.

An unnamed Persoonia from Kroombit Tops, near Gladstone in central-eastern Queensland, closely resembles $P$. volcanica, and is probably its closest relative. Whether it should be named as a new species or as a subspecies of $P$. volcanica remains to be determined.

Selected sPeCimens (9): QueEnSLAND: Moreton: just below summit of Mt Maroon, Grimshaw, 11 Sep 1989 (BRI, NSW); Mt Barney (lower slopes, track up S ridge), Telford, 17 May 1969 (NSW ex CBG); end of Tartars Creek Rd, at border fence, 28 $8^{\circ} 9^{\prime} \mathrm{S} 152^{\circ} 51^{\prime} \mathrm{E}$, Weston $1356 \mathcal{E}$ Richards, 28 Jan 1989 (NSW). New Soutr Wales: North Coast: Wilsons Peak, Maiden, Dec 1907 (NSW 20997); Mahoneys Spur, Levers Plateau, Floyd 500, 20 July 1977 (NSW); Mt Glennie, Constable, 8 Jan 1953 (NSW 22119, BRI).

\title{
Notes on reinstated names, names with changed circumscriptions, and some informal names listed in Jacobs \& Pickard (1981)
}

\author{
Persoonia adenantha Domin \\ (Domin 1921: 582)
}

The taxa that one of us (LJ) previously treated as informal subspecies of $P$. cornifolia in Jacobs \& Pickard (1981) are here treated as species. Although P. adenantha intergrades with $P$. stradbrokensis in the Casino area, it seems reasonable to recognise these taxa at specific rank because they are not necessarily sister species, and their precise relationships with other taxa such as $P$. media are obscure. This requires the reinstatement at specific rank of $P$. adenantha Domin, replacing the informal name $P$. cornifolia subsp. B.

Persoonia attenuata R. Br. (Brown 1830: 16) = P. stradbrokensis Domin x P. virgata $R$. Br.?

Type CitATIOn: 'Ora orient., Moreton Bay, 1827. D. Fraser.'

Holotype: Moreton Bay, Fraser, - (BM).

In Jacobs \& Pickard (1981) the name P. attenuata was misapplied to the taxon that we are now calling $P$. media $R$. Br. Unfortunately, the holotype of $P$. attenuata has 
immature fruits and no flowers, so a number of useful characters are lacking. Of the species that are closely related to $P$. media, it most nearly resembles $P$. volcanica, from which it differs in having comparatively thick, wrinkled leaves in which the lateral venation is obscure, smooth leaf surface, and leaf margins that are scarcely recurved except near the base of the leaf. It most closely matches the few specimens of $P$. stradbrokensis $\times P$. virgata that we have seen, differing from them only in its narrowly to linearly ovate (versus linearly to narrowly oblong to elliptical) leaves.

Persoonia cornifolia Cunn. ex $R . B r$. (Brown 1830: 16)

TYPE CITATION: 'Ora orient., Moreton Bay, 1827. DD. Cunningham et Fraser.'

Holotype: Lat 29 Long 150 1/2 , Cunningham 97, June-July 1827 (BM).

Previously one of us (LJ) had treated this as a polymorphic species with four subspecies. Now we are narrowing its circumscription to that of $P$. cornifolia subsp. D (in Jacobs \& Pickard 1981). P. cornifolia possibly intergrades with $P$. stradbrokensis in the upper Clarence River catchment. $P$. cornifolia differs from $P$. stradbrokensis in having completely smooth (rather than basally flaky) bark, in its predominantly anauxotelic inflorescences with short $(0-0.3 \mathrm{~cm})$ rachises, and its acute to apiculate (never caudate) tepals. Although some specimens of P. stradbrokensis from the Noosa-Cooloola area of Queensland have a high percentage of anauxotelic inflorescences, the rachises in these are mostly $0.5-2.0 \mathrm{~cm}$ long. See also the notes for $P$. rufa and P. oleoides.

Persoonia daphnoides Cunn. ex $\mathrm{R} . \mathrm{Br}$.

(Brown 1830: 15)

TYPE CITATION: 'Ora orient., prope Hunter's River, 1827. D. Cunningham.'

LeCTOTYPE (here designated): Western Branches of Hunter's River, Cunningham 56, (BM). Probable isolectotypes: Bulga Road N from Port Jackson ... Mount Dangar, Cunningham 56, Aug 1827 (K); Hunters River, Cunningham 59, Aug 1827 (K, fragment NSW); also NY.

One of us (LJ) had earlier treated this species as $P$. prostrata subsp. B but, as noted above under $P$. procumbens, we now believe that $P$. daphnoides and $P$. procumbens are sister species and that they are not the closest relatives of $P$. prostrata.

The type location cited by Brown, and recorded on Allan Cunningham's labels, is undoubtedly erroneous as indicated by the following:

Firstly, all known populations of this taxon are restricted to the Tenterfield - Wilsons Downfall area of the Northern Tablelands of New South Wales and adjoining areas in Queensland (Figure 4), at altitudes of 1000 to $1200 \mathrm{~m}$, on Permian adamellite. The type collection has neither flowers nor fruits, but the vegetative material is a good match for specimens from the Tenterfield area. One of us (LJ) has unsuccessfully searched the Mt Dangar area for this species.

Secondly, Cunningham ascended Mt Dangar on 22 April 1825, not in 1827 (E. Webster pers. comm.), so it is clear that his labels are at least partly inaccurate. In the winter of 1827 Cunningham collected in the interior, between the Liverpool Plains and Moreton Bay (E. Webster pers. comm.).

Thirdly, Cunningham supposedly collected other species from Mt Dangar that are otherwise known only from the Tenterfield-Stanthorpe area (W. McDonald pers. comm.). It seems most likely that Cunningham mistakenly transcribed the wrong 
location details from his notebooks to the specimen labels for a whole batch of his specimens from the Tenterfield-Stanthorpe area, including those of $P$. daphnoides.

Persoonia lanceolata Andrews subsp. B = P. glaucescens Sieber ex Sprengel (Sprengel 1827: 45)

Type citation: 'Sieb. ... Nov. Holl',

SYNTYPE (Sieber 47): B.

Originally one of us (LJ) had thought that P. lanceolata Andrews and P. glaucescens Sieber ex Sprengel were allopatric taxa and had treated $P$. glaucescens as $P$. lanceolata subsp. B. Recent fieldwork by one of us (PW) has shown, however, that they occur sympatrically in the Hill Top - Balmoral area, without intergrading. Specific rank is thus appropriate for $P$. glaucescens.

Persoonia media $R . B r$.

(Brown 1830: 16)

Type Citation: 'Ora orient., mont. prope Port Jackson, 1818. D. Fraser.'

HoLOTYPE: Oxley's 2nd Expedition, Fraser 47, - (BM).

[P. attenuata auct. non R. Br. in Jacobs \& Pickard (1981), Stanley \& Ross (1986)]

The name $P$. attenuata was previously misapplied to this species (see above) and so the name $P$. media (previously treated as a synonym of $P$. attenuata) must be reinstated. $P$. media occurs in New South Wales on the escarpment of the Northern Tableands from the northern Barrington Tops to Chaelundi Mountain and on the Nightcap Range and in south-eastern Queensland on the Lamington and Springbrook Plateaus. On the eastern edge of the Northern Tablelands between the Macleay and Manning Rivers, P. media seems to show clinal, intraspecific variability. This variation is ecologically correlated: on the driest sites (dry sclerophyll forest) the plants are usually multistemmed, lignotuberous, $0.3-2 \mathrm{~m}$ high, having short, anauxotelic inflorescences as well as, or instead of, auxotelic inflorescences. These specimens constitute $P$. attenuata subsp. B in Jacobs \& Pickard (1981). Plants on the wettest sites (rainforest margins) are taller, (0.7-)2-8 m high, single-stemmed, produce only auxotelic inflorescences and on average have narrower leaves than the multi-stemmed plants. These specimens constitute, in part, P. attenuata subsp. A in Jacobs \& Pickard (1981). In other characters these extreme forms resemble each other more closely than specimens from north of the Macleay (which were also included in subsp. A). Moreover, populations of $P$. media north of the Macleay show geographically correlated morphological variation, so the pattern of infraspecific variation is quite complicated. Consequently, we have chosen not to recogise any formal infraspecific taxa.

Persoonia prostrata $R . B r$.

(Brown 1810: 163)

TYPE CrTATION: 'In Novae Hollandiae ora orientali; prope Sandy Cape'.

LeCTOTYPE (here designated): Sandy Cape, Hervey's Bay, R. Brown, 31 July 1802 (BM). ISOLECTOTYPE: NSW.

As discussed above, under $P$. procumbens, we are applying the name $P$. prostrata only to specimens from Fraser Island, in south-eastern Queensland.

$P$. prostrata is very similar to specimens of $P$. stradbrokensis collected from the mainland south of Fraser Island, but differs in its prostrate habit, usually smaller leaves 
and smaller flowers. These differences are based on only two collections for $P$. prostrata, neither of which is an adequate specimen. It may be that $P$. prostrata and $P$. stradbrokensis are conspecific, and that $P$. prostrata is just a prostrate, maritime form. However, the distributions of these species are separated by over 100 kilometres and one of us (PW) has briefly traversed much of this intervening country without finding either species. If these taxa prove to be conspecific, there are unfortunate nomenclatural implications: $P$. prostrata (an inappropriate epithet for a combined taxon usually plants are erect shrubs to trees up to $8 \mathrm{~m}$ high) would have priority over $P$. stradbrokensis. It seems wisest to continue to recognise these entities as distinct taxa.

Recently, one of us (PW) failed to find P. prostrata despite searching the Bool Creek area, south-west of Sandy Cape, where Flinders and Brown landed in 1802. Brown (1810: 163) noted that he collected it 'prope Sandy Cape; in arenosis prope littora'. That $P$. prostrata does (or did) occur there is confirmed by the only other specimen, that collected by Miss S. Lovell, the school teacher at Sandy Cape during the late 19th and early 20th centuries. Apparently the northern end of Fraser Island is being eroded by the sea and it is possible that $P$. prostrata existed as a small population that is now extinct.

\section{Persoonia stradbrokensis Domin}

(Domin 1921: 580)

We are reinstating this name for the taxon that one of us (LJ) had informally named $P$. cornifolia subsp. A in Jacobs \& Pickard (1981).

Persoonia sp. B (aff. virgata) = P. cornifolia Cunn. ex $R . B r . \times$ P. tenuifolia $R$. Br., P. sericea Cunn. ex $R$. Br. x P. tenuifolia $R$. Br., P. stradbrokensis Domin $\times$ P. tenuifolia $R$. $B r$.

The leaves of $P$. tenuifolia are so different from those of most other species of Persoonia (linear-filiform, 0.3-0.5 mm wide, terete and grooved on upper surface) that hybrids of it with relatively broad-leaved species do not resemble either parent closely. Consequently it is not surprising that such hybrids have been tentatively recognised as new taxa in the past. We have recently observed that $P$. tenuifolia apparently hybridises sporadically with $P$. stradbrokensis, where these taxa occur sympatrically at Kremnos Creek, south of Grafton. These hybrids are indistinguishable from specimens from the Grafton area that were attributed to P. sp. B. (aff. virgata). A few similar specimens, collected where $P$. tenuifolia is sympatric with $P$. cornifolia in the Torrington area, and with $P$. sericea in the Yetman area, presumably are also hybrids.

\section{Persoonia sp. $\mathrm{E}=\mathbf{P}$. cornifolia Cunn. ex $R . B r . \times$ P. fastigiata $R . B r$.}

Specimens that were attributed to $P . \mathrm{sp}$. E are morphologically intermediate between $P$. fastigiata and $P$. cornifolia, and this prompted us to postulate that they were hybrids. One of us (PW) tested this idea by visiting a locality at which both presumed parents (but not P. sp. E) had been collected previously, Parlor Mountain. Both parents were re-collected there as well as plants attributable to $P$. sp. E that apparently formed part of a hybrid swarm.

Persoonia sp. F (aff. oblongata) $=$ P. levis (Cav.) Domin $\times$ P. oxycoccoides Sieber ex Sprengel

This hybrid is represented by only four specimens, all from the Carrington Falls area. They are intermediate between the presumed parents in all respects except bark morphology; where noted, the bark was observed to be smooth and compact. Collectors have noted either that the hybrid was rare, or that they saw only one plant. One of 
us (PW) has collected one specimen of this hybrid, where it was growing sympatrically with both parents as well as $P$. mollis subsp. ledifolia and $P$. laurina subsp. leiogyna.

\section{Acknowledgements}

We are most grateful to the following individuals for assisting with this project. Don Foreman, Siegfried Krauss and Karen Wilson critically read earlier drafts of the manuscript. Barbara Briggs and Merle Johnson assisted LJ at early stages of the project. Peter Richards, Siegfried Krauss and David Tomlinson accompanied PW on a number of field trips devoted to collecting Persoonias. Elsie Webster and Bill McDonald (BRI) provided unpublished information on Allan Cunningham's collections. Surrey Jacobs searched for type specimens of Persoon's species at Leiden, in his capacity as Australian Botanical Liaison Officer at Kew. Michael Crisp provided copies of some original descriptions. Peter Richards and Diane Godden drafted the maps. We are grateful to the Directors of the following institutions for giving us access to their collections as visiting workers or through loans of specimens: B, BM, BRI, K, M, MEL, NY, SYD.

\section{References}

Bentham, G. (1870) Flora Australiensis, vol. 5 (L. Reeve \& Co.: London).

Briggs, B.G. \& Johnson, L.A.S. (1979) Evolution in the Myrtaceae - evidence from inflorescence structure. Proc. Linn. Soc. New South Wales 102: 157-256.

Briggs, J.D. \& Leigh, J.H. (1988) Rare or threatened Australian plants. Australian National Parks \& Wildlife Service Special Publication no. 14.

Brown, R. (1810) On the natural order of plants called Proteaceae. Trans. Linn. Soc. 10: 15-226.

Brown, R. (1830) Supplementum primum prodromi florae Novae Hollandiae (Richard Taylor: London).

Domin, K. (1921) Beiträge zur flora und pflanzengeographie Australiens, I. Teil. 3. Abteilung. Lieferung 1. Bibliotheca Botanica 89: 555-643.

Endlicher, S.L. (1848) Genera plantarum supplementum quartum pars II. (Friedrich Beck: Vienna).

Gandoger, M. (1919) Sertum plantum novarum. Pars secunda. Bull. Soc. Bot. France 66: 216-233, 286-307.

Hickey, L.J. (1973) Classification of the architecture of dicotyledonous leaves. Amer. J.Bot. 60: $17-33$.

Jacobs, S.W.L. \& Pickard, J. (1981) Plants of New South Wales (Govt Printer: Sydney).

Kuntze, O. (1891) Revisio generum plantarum, part 2. (Felix: Leipzig).

Meissner, C.D.F. (1855) New Proteaceae of Australia. Hooker's J. Bot. Kew Gard. Misc. 7: 65-78.

Meissner, C.D.F. (1856) Proteaceae. Pp. 209-482 in A. de Candolle (ed.), Prodromus systematis naturalis regni vegetabilis, vol. 14 (Victor Masson: Paris).

Persoon, C.H. (1805) Synopsis plantarum 1 (C.F. Cramer: Paris \& J.C. Cotta: Tübingen).

Schultes, J.A. \& Schultes, J.A. (1827) Mantissa systematis vegetabilium 3 (J.C. Cotta: Stuttgart).

Smith, J.E. (1805-1808) Exotic Botany 2 (R. Taylor and Co.: London).

Sprengel, C. (1827) Systema vegetabilium Editio Decima Sexta, 4(2) Curae Posteriores (Librariae Dieterichianae: Gottingen).

Stanley, T.D. \& Ross, E.M. (1986) Flora of south-eastern Queensland, Vol. 2 (Queensland Department of Primary Industries: Brisbane).

Weston, P.H. (1983) The systematics and biogeography of the Persooniinae (Proteaceae) (unpublished Ph.D. thesis, University of Sydney). 


\section{Index}

New names and combinations are printed in boldface, synonyms are printed in italics.

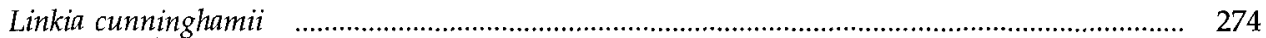

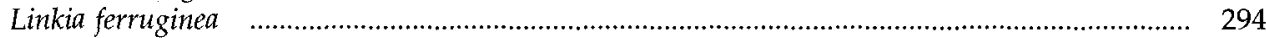

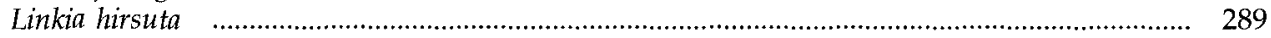

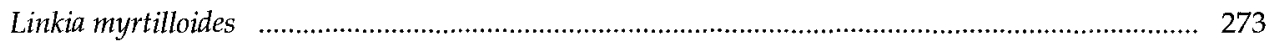

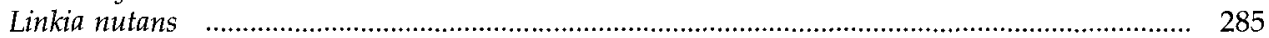

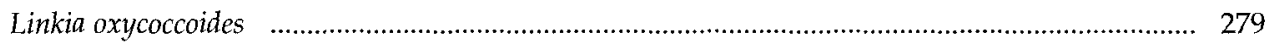

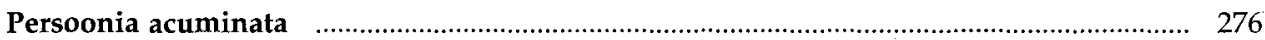

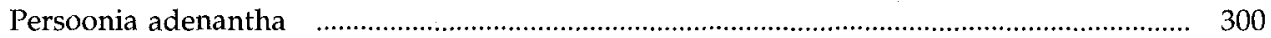

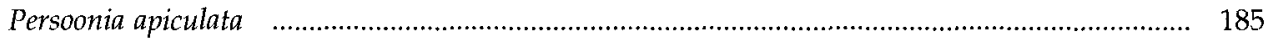

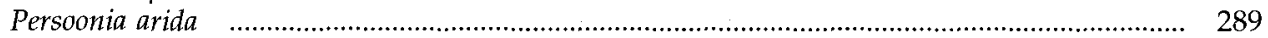

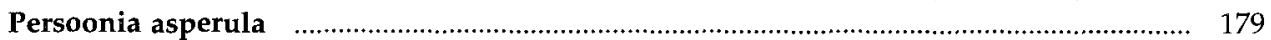

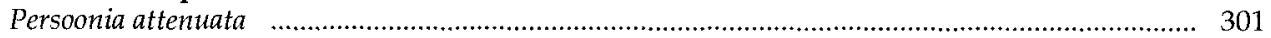

Persoonia attenuata auct. .............................................................................................. 302

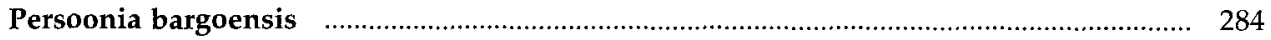

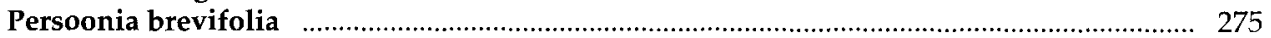

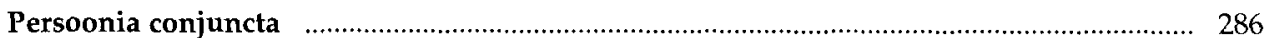

Persoonia cornifolia .............................................................................................. 301, 303

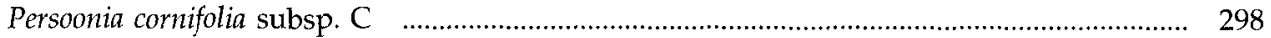

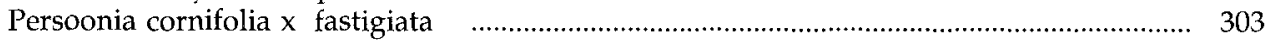

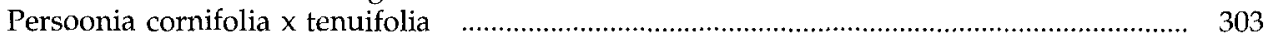

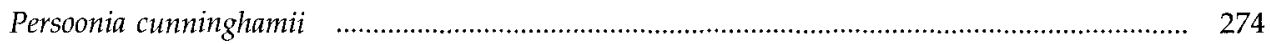

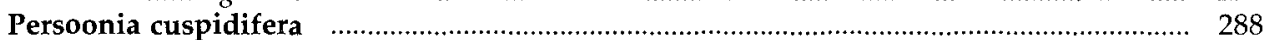

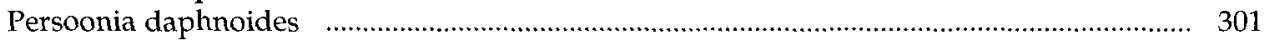

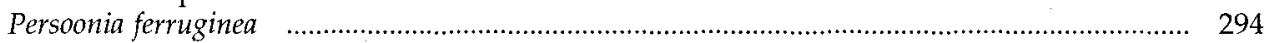

Persoonia glaucescens $\quad$...................................................................................................... 302

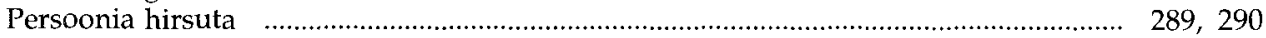

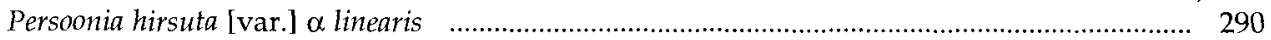

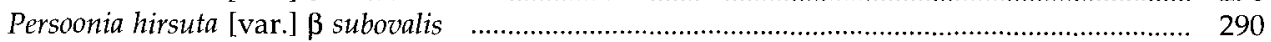

Persoonia hirsuta [var.] y spathulata ............................................................................ 290

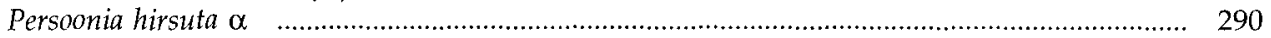

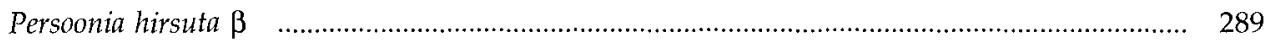

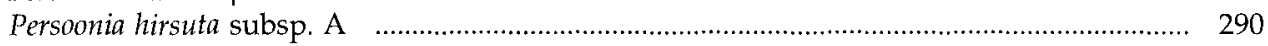

Persoonia hirsuta subsp. B ........................................................................................... 290

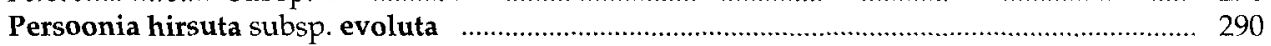

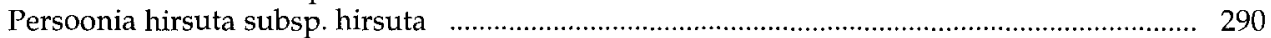

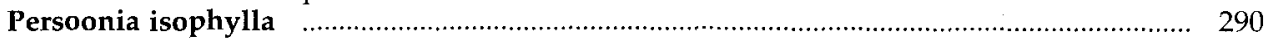

Persoonia katerae

Persoonia lanceolata subsp. B …….................................................................................. 303

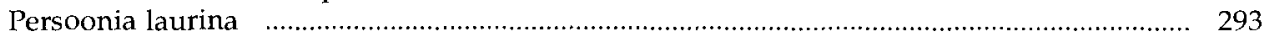

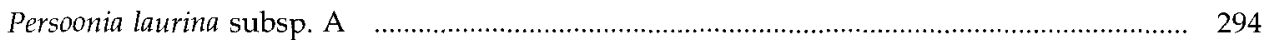

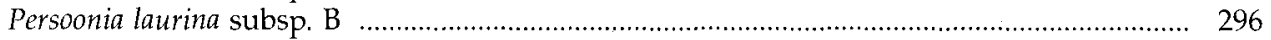

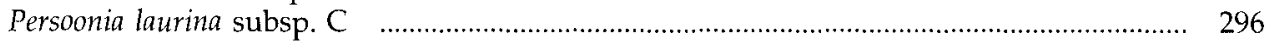

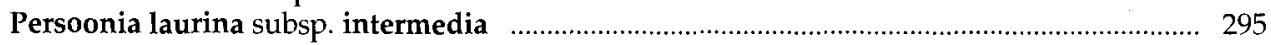

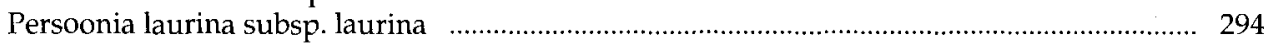

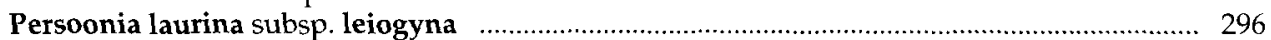

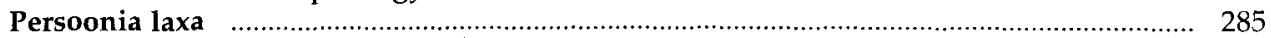

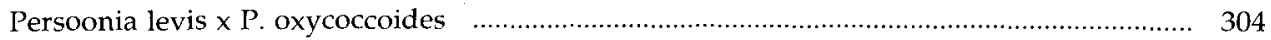

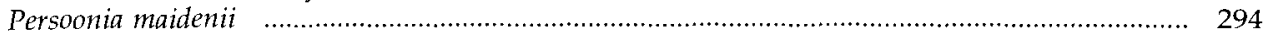

Persoonia media

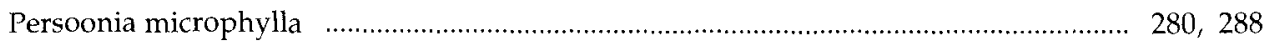

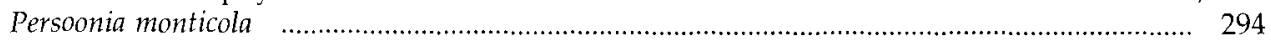

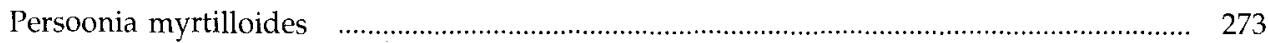




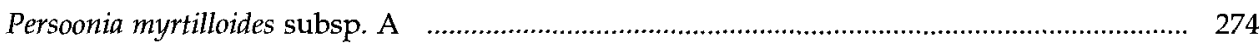

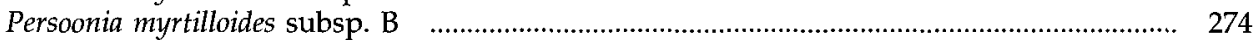

Persoonia myrtilloides subsp. cunninghamii ................................................................. 274

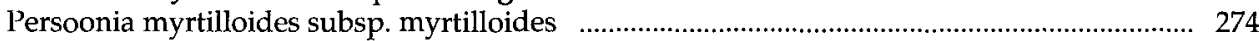

Persoonia myrtilloides var. brevifolia

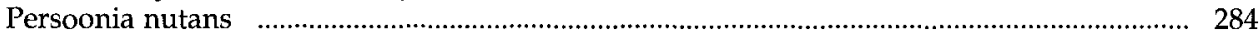

Persoonia nutans var. apiculata

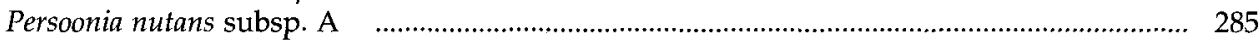

Persoonia nutans subsp. B $\quad$................................................................................................... 285

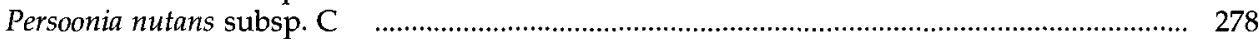

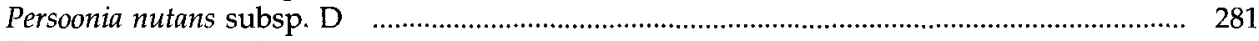

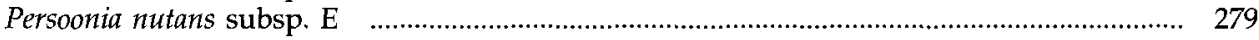

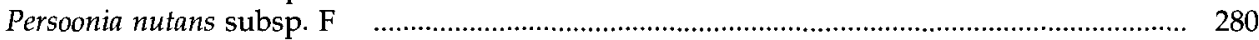

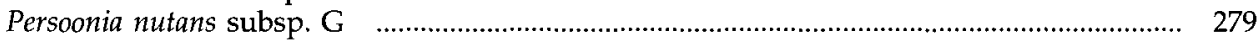

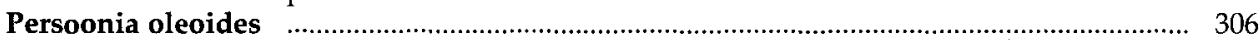

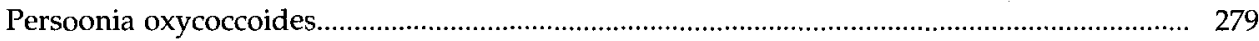

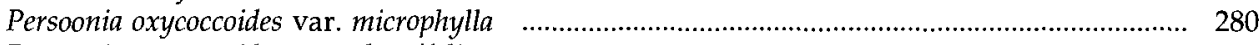

Persoonia oxycoccoides var.? longifolia _................................................................................... 276

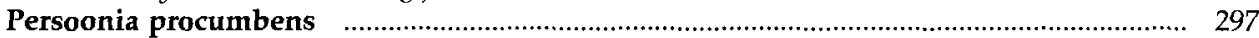

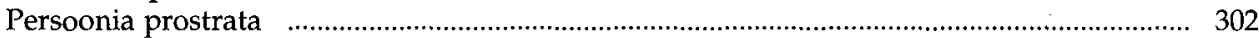

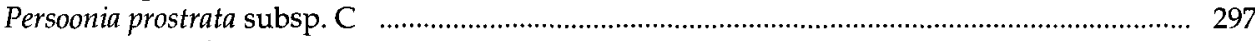

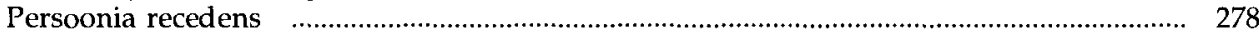

Persoonia rigida var. microphylla _....................................................................................... 288

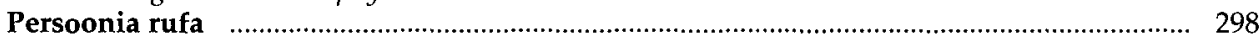

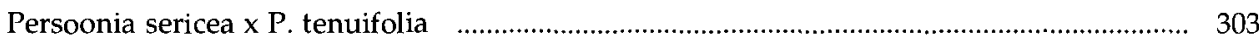

Persoonia sp. A (aff. pinifolia) ........................................................................................ 291

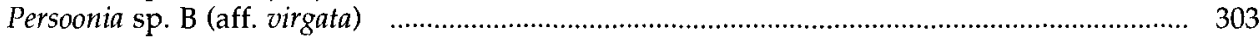

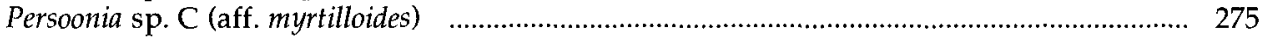

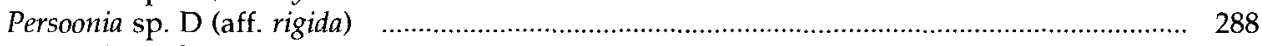

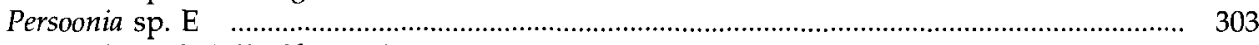

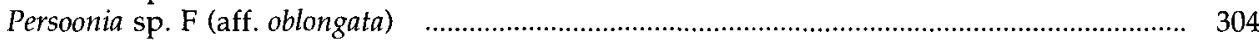

Persoonia stradbrokensis ................................................................................................. 303

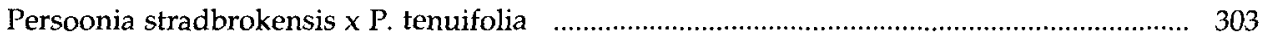

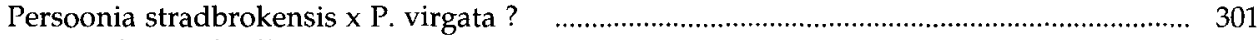

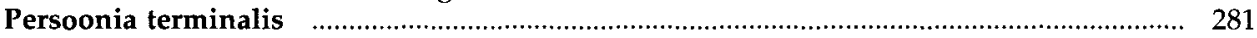

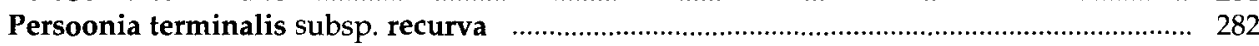

Persoonia terminalis subsp. terminalis ……............................................................... 282

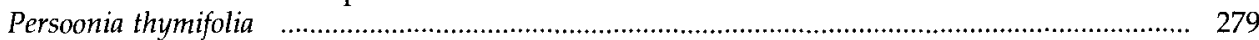

Persoonia volcanica

Manuscript received 31 May 1990

Manuscript accepted 30 November 1990 